\title{
Article
}

\section{Therapeutic Effects of Hydrogen Gas Inhalation on Trimethyltin-Induced Neurotoxicity and Cognitive Impairment in the C57BL/6 Mice Model}

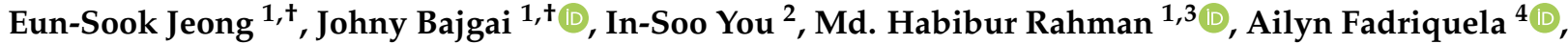 \\ Subham Sharma ${ }^{1,3}$, Hwang-Un Kwon ${ }^{2}$, So-Yeon Lee ${ }^{2}$, Cheol-Su Kim ${ }^{1}{ }^{10}$ and Kyu-Jae Lee ${ }^{1, *}$
}

1 Department of Environmental Medical Biology, Wonju College of Medicine, Yonsei University, Wonju 26426, Korea; micca08@naver.com (E.-S.J.); johnybajgai@yonsei.ac.kr (J.B.);

pharmacisthabib@yonsei.ac.kr (M.H.R.); subhamsharma047@gmail.com (S.S.); cs-kim@yonsei.ac.kr (C.-S.K.)

2 GOOTZ Co., Ltd., 79-6, Yuljeong-ro 247 beon-gil, Yangju-si, Suwon 11457, Korea; igootz@naver.com (I.-S.Y.); kwon@mygootz.com (H.-U.K.); sylee@mygootz.com (S.-Y.L.)

3 Department of Global Medical Science, Wonju College of Medicine, Yonsei University, Wonju 26426, Korea

4 Department of Laboratory Medicine, Wonju College of Medicine, Yonsei University, Wonju 26426, Korea; ailyn@yonsei.ac.kr

* Correspondence: medbio@yonsei.ac.kr; Tel.: +82-(033)-741-331

+ These authors contributed equally to this work as first authors.

Citation: Jeong, E.-S.; Bajgai, J.;

You, I.-S.; Rahman, M.H.;

Fadriquela, A.; Sharma, S.; Kwon,

H.-U.; Lee, S.-Y.; Kim, C.-S.; Lee, K.-J.

Therapeutic Effects of Hydrogen Gas

Inhalation on Trimethyltin-Induced

Neurotoxicity and Cognitive

Impairment in the C57BL/6 Mice

Model. Int. J. Mol. Sci. 2021, 22, 13313.

https://doi.org/10.3390/

ijms222413313

Academic Editor: Isabella Zanella

Received: 8 November 2021

Accepted: 7 December 2021

Published: 10 December 2021

Publisher's Note: MDPI stays neutral with regard to jurisdictional claims in published maps and institutional affiliations.

Copyright: (C) 2021 by the authors. Licensee MDPI, Basel, Switzerland. This article is an open access article distributed under the terms and conditions of the Creative Commons Attribution (CC BY) license (https:// creativecommons.org/licenses/by/ $4.0 /)$.

\begin{abstract}
Oxidative stress (OS) is one of the causative factors in the pathogenesis of various neurodegenerative diseases, including Alzheimer's disease (AD) and cognitive dysfunction. In the present study, we investigated the effects of hydrogen $\left(\mathrm{H}_{2}\right)$ gas inhalation in trimethyltin (TMT)-induced neurotoxicity and cognitive dysfunction in the C57BL/6 mice. First, mice were divided into the following groups: mice without TMT injection (NC), TMT-only injection group (TMT only), TMT injection + lithium chloride-treated group as a positive control (PC), and TMT injection $+2 \% \mathrm{H}_{2}$ inhalation-treated group $\left(\mathrm{H}_{2}\right)$. The TMT injection groups were administered a single dosage of intraperitoneal TMT injection ( $2.6 \mathrm{mg} / \mathrm{kg}$ body weight) and the $\mathrm{H}_{2}$ group was treated with $2 \% \mathrm{H}_{2}$ for $30 \mathrm{~min}$ once a day for four weeks. Additionally, a behavioral test was performed with Y-maze to test the cognitive abilities of the mice. Furthermore, multiple OS- and AD-related biomarkers such as reactive oxygen species (ROS), nitric oxide (NO), calcium $\left(\mathrm{Ca}^{2+}\right)$, malondialdehyde (MDA), glutathione peroxidase (GPx), catalase, inflammatory cytokines, apolipoprotein E (Apo-E), amyloid $\beta$ (A $\beta$ )-40, phospho-tau (p-tau), Bcl-2, and Bcl-2- associated X (Bax) were investigated in the blood and brain. Our results demonstrated that TMT exposure alters seizure and spatial recognition memory. However, after $\mathrm{H}_{2}$ treatment, memory deficits were ameliorated. $\mathrm{H}_{2}$ treatment also decreased AD-related biomarkers, such as Apo-E, A $\beta-40$, p-tau, and Bax and OS markers such as ROS, NO, $\mathrm{Ca}^{2+}$, and MDA in both serum and brain. In contrast, catalase and GPx activities were significantly increased in the TMT-only group and decreased after $\mathrm{H}_{2}$ gas treatment in serum and brain. In addition, inflammatory cytokines such as granulocyte colony-stimulating factors (G-CSF), interleukin (IL)-6, and tumor necrosis factor alpha (TNF- $\alpha$ ) were found to be significantly decreased after $\mathrm{H}_{2}$ treatment in both serum and brain lysates. In contrast, Bcl-2 and vascular endothelial growth factor (VEGF) expression levels were found to be enhanced after $\mathrm{H}_{2}$ treatment. Taken together, our results demonstrated that $2 \% \mathrm{H}_{2}$ gas inhalation in TMT-treated mice exhibits memory enhancing activity and decreases the AD, OS, and inflammatory-related markers. Therefore, $\mathrm{H}_{2}$ might be a candidate for repairing neurodegenerative diseases with cognitive dysfunction. However, further mechanistic studies are needed to fully clarify the effects of $\mathrm{H}_{2}$ inhalation on TMT-induced neurotoxicity and cognitive dysfunction.
\end{abstract}

Keywords: molecular hydrogen; trimethyltin; oxidative stress; Alzheimer's disease; cognitive dysfunction 


\section{Introduction}

Neurodegenerative diseases are groups of different aging disorders such as Alzheimer's disease (AD), Parkinson's disease, amyotrophic lateral sclerosis, and Huntington's disease, which gradually lead to an increase in neuronal cells, the accumulation of abnormally aggregated proteins, and apoptosis, ultimately affecting the motor and cognitive function of an individual [1]. AD is the most extensively reported neurodegenerative disease to date and is associated with complex and multifactorial pathophysiology [2,3]. Although there are several factors associated with the development of $A D$, amyloid $\beta(A \beta)$ and tau protein are most closely associated with its pathogenesis [4-6]. A $\beta$ abnormally accumulates in $\mathrm{AD}$ brain tissues and forms extracellular plaques that are known to induce synaptic alterations and neurodegeneration and may contribute to cognitive deficit [4]. On the other hand, hyperphosphorylation of tau protein forms intracellular neurofibrillary tangles (NFT) and is strongly responsible for neurodegeneration [5,6]. In addition, increasing evidence shows that oxidative stress (OS) plays a significant role in the progression of neurodegenerative diseases and neurodegeneration, as it contributes to the destruction of membranes, cytoskeleton alterations, and apoptosis due to excessive production of reactive oxygen species (ROS), reactive nitrogen species (RNS), and inflammatory mediators such as inflammatory cytokines [1,7-10]. In $\mathrm{AD}$, due to oxidative imbalance-mediated injury to the brain region, lipid peroxidation markers are found to be elevated and extensively studied in its pathogenesis [9]. Therefore, OS may easily cause degeneration in the hippocampal region in brain, which is the major region for memory processing [11,12]. Thus, to ameliorate neurodegenerative diseases such as $\mathrm{AD}$, different therapeutic approaches are developing at a rapid pace. Therefore, several animal models, such as TMT-induced neurodegeneration are often used for exploring the effects of therapeutic candidates on neurodegenerative diseases such as AD.

Trimethyltin (TMT) is a neurotoxin and organometallic compound that induces substantial neurodegeneration and neuronal cell death in the central nervous system (CNS), particularly in the hippocampus region in the brain [13]. Several studies have shown that the systemic administration of TMT in human and mice demonstrated clinical symptoms, such as hyperactivity, aggressiveness, cognitive deficits, and seizure-like behaviors [13-15]. However, evidence shows that all of these symptoms are associated with AD [2,6]. Additionally, previously conducted experimental observations suggest that TMT-induction induces neuronal cell death, intracellular calcium $\left(\mathrm{Ca}^{2+}\right)$ overload, mitochondrial damage, and OS [16-18]. Moreover, TMT-induction enhances neurogenesis in the brain and increases the expression of the amyloid precursor protein, several signaling pathways, inflammatory cytokines such as tumor necrosis factor alpha (TNF- $\alpha$ ), interleukin (IL)-1 $\beta$, and nitric oxide (NO) levels in the hippocampus region, and might be involved in brain injury [19-22]. Due to this reason, the TMT-induced animal model is widely used in research for investigating brain dysfunction and neurodegeneration [11,23]. From these background studies, it is important to find an excellent multi-potent agent with antioxidant and antiinflammatory properties for repairing the brain cells against TMT-induced neurotoxicity and cognitive impairment.

Molecular hydrogen $\left(\mathrm{H}_{2}\right)$ is potential novel antioxidant, and previously published studies have strongly suggested its potential for preventive and therapeutic applications [24-26]. In recent years, research on $\mathrm{H}_{2}$ therapy for neurodegenerative diseases such as AD has become a hotspot due to its anti-oxidative, anti-apoptotic, and anti-inflammatory effects $[25,27]$. So far, several animal experiments and more than 25 double-blinded clinical studies have been reported regarding the efficacies of $\mathrm{H}_{2}[25,26]$. Administration of $\mathrm{H}_{2}$ gas by inhalation can readily penetrate through biomembranes, such as the bloodbrain barrier (BBB) and the placental barrier owing to its small molecular size, non-ionic state, and hydrophobic properties, thus benefiting complex organs such as the brain and organelles $[28,29]$. Several studies have reported that $\mathrm{H}_{2}$ plays a positive role in neuroprotection under conditions such as cerebral infarction, Parkinson's disease, cognitive impairment, and brain injury by attenuating OS and the inflammatory response [26,28,30-34]. In 
previous studies conducted using an inflammatory disease model, the administration of $\mathrm{H}_{2}$ caused anti-inflammatory response by ameliorating the pro-inflammatory markers, such as TNF- $\alpha$, IL-1 $\beta$, and IL-6 $[26,30,32]$. In addition, Iuchi and colleagues demonstrated that administration of $\mathrm{H}_{2}$ (approximately $1 \%, v / v$ ) modulated the $\mathrm{Ca}^{2+}$ signal and modified the generation of oxidized phospholipid species [35]. Recently, Zhou and colleagues reported that hydrogen-rich water has potential to ameliorate TMT-induced memory impairment by regulating Siah E3 ubiquitin protein ligase 1 [36]. However, the therapeutic effects of $\mathrm{H}_{2}$ on chemically induced neurodegenerative diseases model such as the TMT-induced animal model are poorly studied. Consequently, the actual molecular mechanism through which $\mathrm{H}_{2}$ treatment induces CNS protection against TMT-induced neurotoxicity and cognitive dysfunction has not been yet fully elucidated. Therefore, based on the neurodegenerative and oxidative damage of TMT, as well as the antioxidative and anti-inflammatory characteristics of hydrogen, the present study aimed to investigate the potential therapeutic effects of $2 \% \mathrm{H}_{2}$ gas inhalation on TMT-induced neurotoxicity and cognitive impairment in a TMT-induced neurodegenerative mouse model. In addition, we explored the effects of $\mathrm{H}_{2}$ in the TMT-induced oxidative and inflammatory response in serum and brain lysates.

\section{Results}

2.1. Effects of $\mathrm{H}_{2}$ Gas Inhalation in TMT-Induced C57BL/6 Mice on Seizure Behavior and Body Weight Measurement

The TMT injection, $\mathrm{H}_{2}$ administration, and all experimental procedures were conducted following the timeline indicated in Figure 1. TMT induction is known to induce seizure behavior in mice [13]. In our study, we tested the effects of $\mathrm{H}_{2}$ gas inhalation on seizure-like behaviors in TMT-induced mice. During the experiment, with TMT induction, symptoms such as tremors, seizures, and aggressive behavior were observed in mice for four days. However, administration of $\mathrm{PC}$ and $\mathrm{H}_{2}$ treatment resulted in a significant decrease in seizure-like behaviors from day 2 to 4 (Figure 2A). On day $2(p<0.05)$, day $3(p<0.001)$, and day $4(p<0.01)$, the behavioral seizure score showed a significant reduction in the PC-treated group compared to the TMT-only group. Likewise, administration of $\mathrm{H}_{2}$ also significantly decreased seizure-like behaviors in TMT-induced mice from day $2(p<0.05)$, day $3(p<0.05)$, and day $4(p<0.001)$ compared to the TMT-only group (Figure 2A). These results indicate that administration of $\mathrm{H}_{2}$ gas inhalation reduced seizure-like behaviors in TMT-induced mice. Additionally, the body weight was measured once per week for four weeks to obtain baseline data. Our results showed that TMT induction led to a slight decrease in body weight on the 7th day in the TMT-only group compared to the $\mathrm{NC}, \mathrm{PC}$, and $\mathrm{H}_{2}$ groups. However, the difference was not significant (Figure $2 \mathrm{~B}$ ).

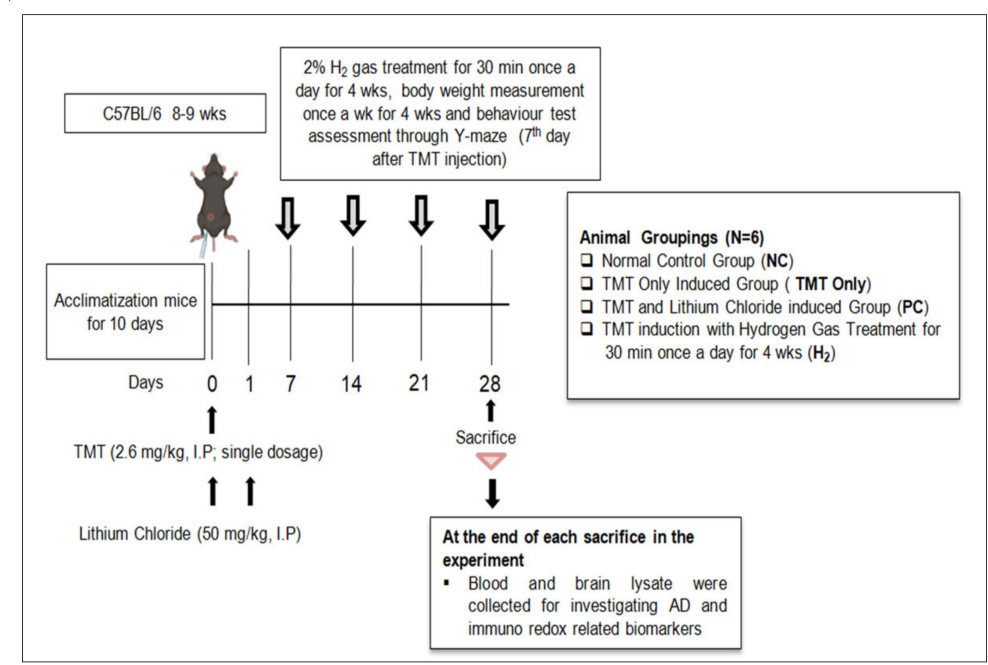

Figure 1. Schematic diagram of the experimental process. 
A

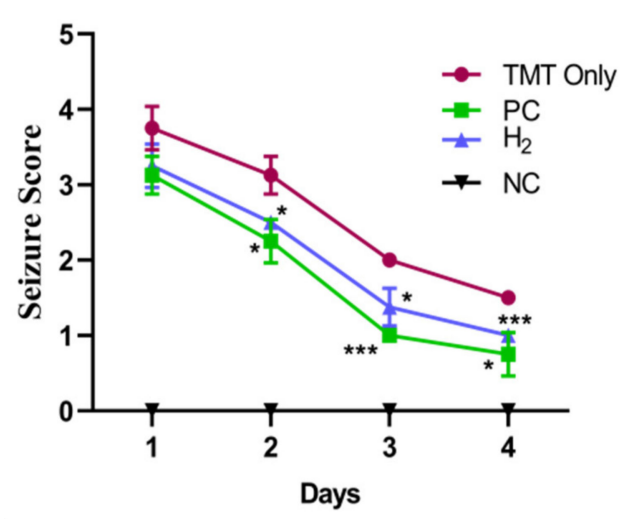

B

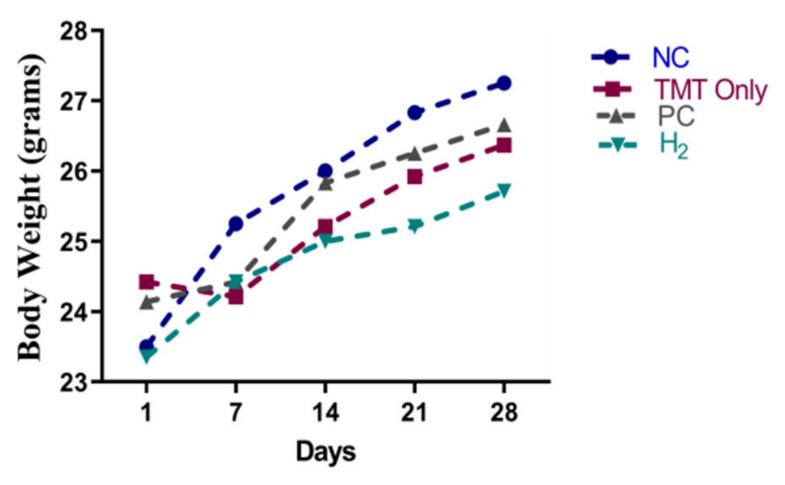

Figure 2. Effects of $\mathrm{H}_{2}$ gas inhalation treatment on the seizure behavior (A) and body weight (B) of the TMT-induced C57BL $/ 6$ mice. Data are shown as the mean \pm SEM for $\mathrm{n}=4$ mice. Significant differences were analyzed with ANOVA and Tukey's test. ${ }^{*} p<0.05,{ }^{* * *} p<0.001$ compared with TMT-only group.

\subsection{Effects of $\mathrm{H}_{2}$ Gas Inhalation on TMT-Induced Cognitive Dysfunction}

To investigate the effects of $\mathrm{H}_{2}$ gas inhalation on TMT-induced cognitive dysfunction, TMT was injected intraperitoneally (ip) in mice, and $2 \% \mathrm{H}_{2}$ gas was administered for four weeks. Since the Y-maze test was conducted to determine spatial cognition and short-term abilities, we performed the Y-maze test on day 7 after TMT induction to determine the willingness of mice to explore new circumstances and to assess their short-term memory. We found that spontaneous alternation (\%) of the TMT-only group was decreased compared to the NC-, $\mathrm{PC}-$, and $\mathrm{H}_{2}$-treated groups (Figure $3 \mathrm{~A}$ ). In addition, we found significantly increased distance travel in the maze compartment zone in the TMT-only group $(p<0.001)$ compared to that in the NC-, $\mathrm{PC}-$, and $\mathrm{H}_{2}$-treated groups (Figure $3 \mathrm{~B}$ ). A previous study reported that TMT-exposed animals showed cognitive impairment as well as hyperactive behavior compared to the control group [13], which is consistent with our findings in this study. Therefore, our results suggest that $\mathrm{H}_{2}$ can attenuate the TMT-induced impairment of the spatial working memory and hyperactivity in mice. However, more types of maze experiments are needed to fully confirm this notion.
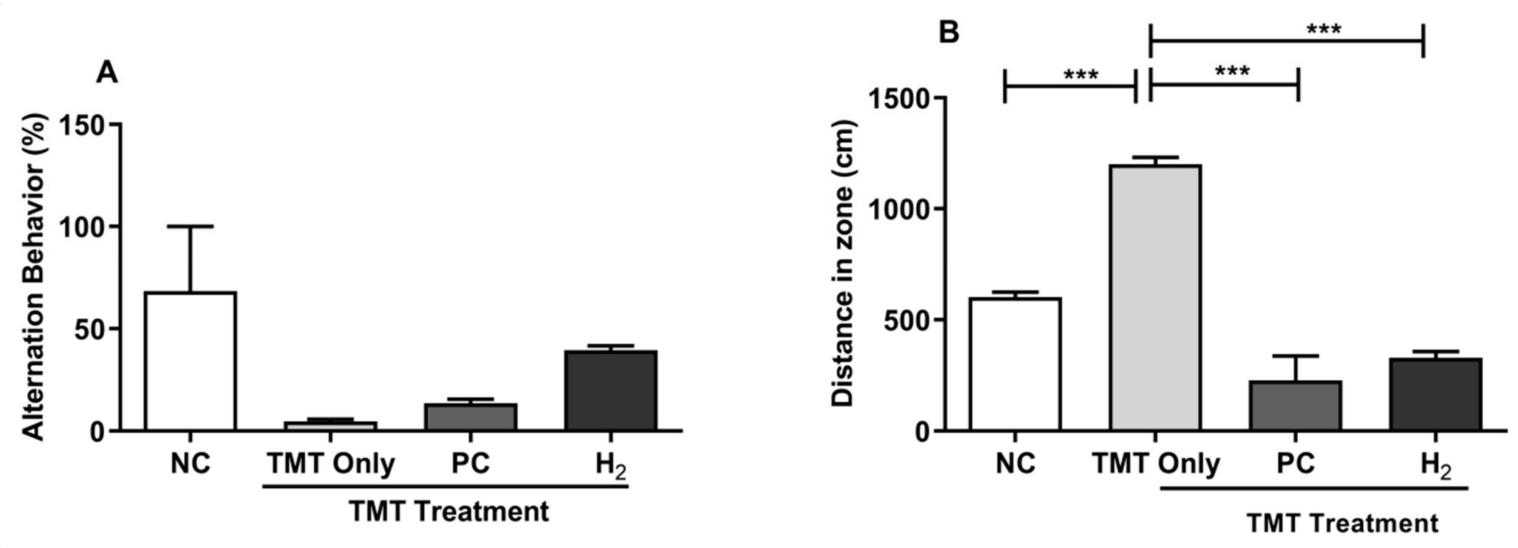

Figure 3. Effects of $\mathrm{H}_{2}$ gas inhalation treatment on TMT-induced spatial cognitive impairment in C57BL/6 mice. After TMT induction ( $2.6 \mathrm{mg} / \mathrm{kg}$ body weight), $2 \% \mathrm{H}_{2}$ gas and lithium chloride (PC, $50 \mathrm{mg} / \mathrm{kg}$ body weight) were ip administered to six mice. (A) Alternation behavior on day 7. (B) Distance traveled in the Y-maze compartment. Data are shown as the mean \pm SEM for $\mathrm{n}=4$ mice. Significant differences were analyzed with ANOVA and Tukey's test. ${ }^{* * *} p<0.001$. 


\subsection{Effects of $\mathrm{H}_{2}$ Gas Inhalation on TMT-Induced ROS and NO Levels in Mice Serum and Brain}

OS is considered one of the known toxic mechanisms of TMT induction [13]. Thus, to investigate the effects of $\mathrm{H}_{2}$ gas inhalation on TMT-induced neuronal toxicity, we analyzed the total ROS and NO levels in both the serum and brain lysates of C57BL/ 6 mice. Our results showed a significant increase in total intracellular ROS levels $(p<0.05)$ and NO levels $(p<0.01)$ in the serum of the TMT-only group compared to the NC group (Figure 4A,C). Additionally, we found that the ROS and NO levels were markedly increased in the brain lysates of the TMT-only group $(p<0.001$, and $p<0.01)$ compared with the NC group (Figure 4B,D). In contrast, ROS levels were significantly decreased in the brain of the $\mathrm{H}_{2}$-treated $(p<0.01)$ and PC-treated groups $(p<0.01)$ compared with the TMT-only group (Figure 4B). Additionally, upon $\mathrm{H}_{2}$ treatment, TMT-induced NO levels were significantly decreased $(p<0.01)$ compared to the TMT-only group (Figure 4D). Taken together, our results showed that with $\mathrm{H}_{2}$ gas treatment, both OS markers, i.e., ROS and NO, were effective in repairing TMT-induced neuronal damage.

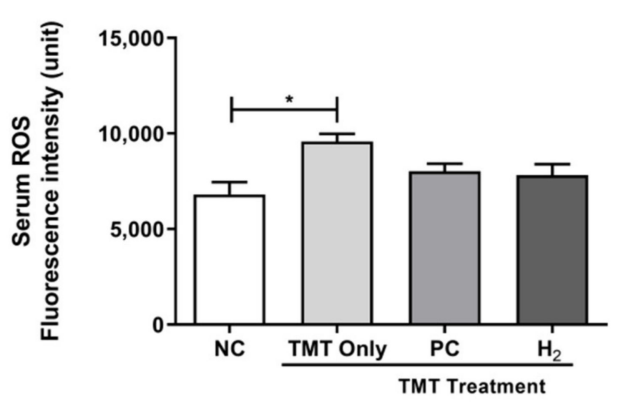

C

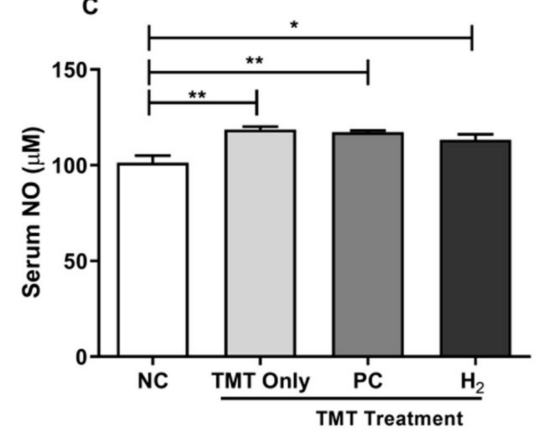

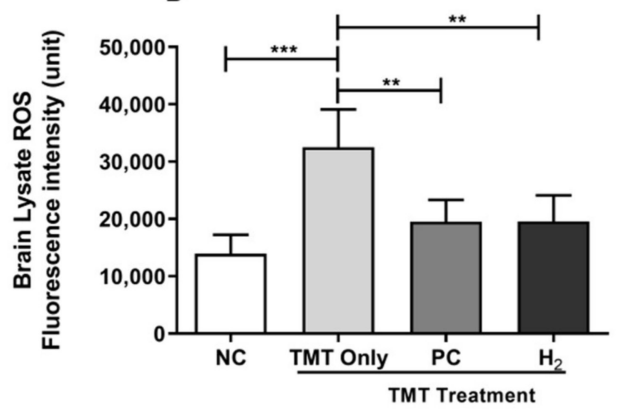

D

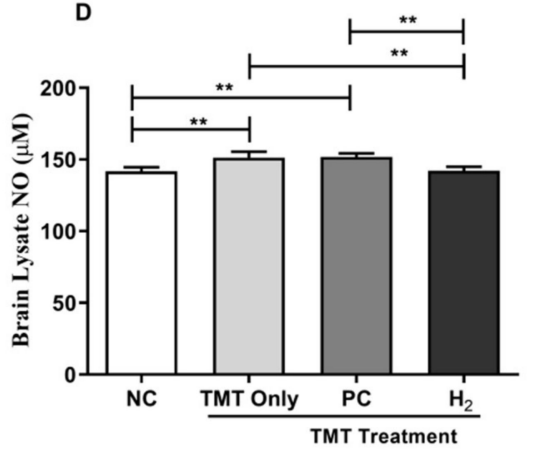

Figure 4. Effects of $\mathrm{H}_{2}$ gas inhalation treatment on total ROS and NO levels in TMT-induced C57BL/6 mice after four weeks. (A) Serum ROS, (B) Brain lysates ROS, (C) Serum NO, and (D) Brain lysates NO levels. Data are shown as the mean \pm SEM for $n=4$ mice. Significant differences were analyzed with ANOVA and Tukey's test. ${ }^{*} p<0.05,{ }^{* *} p<0.01,{ }^{* * *} p<0.001$.

\subsection{Effects of $\mathrm{H}_{2}$ Gas Inhalation on TMT-Induced $\mathrm{Ca}^{2+}$ and Malondialdehyde Levels in Mice Serum and Brain}

The role of lipid peroxidation and intracellular $\mathrm{Ca}^{2+}$ has been extensively studied in AD pathogenesis [11,16]. Malondialdehyde (MDA) is an indicator of lipid peroxidation induced by OS [9]. In our study, we investigated the effects of $\mathrm{H}_{2}$ inhalation on TMTinduced $\mathrm{Ca}^{2+}$ and lipid peroxidation levels in C57BL/ 6 mice in both the serum and brain lysates. As shown in Figure 5A,B, the $\mathrm{Ca}^{2+}$ level in both the serum and brain lysates of the TMT-only mice showed higher values compared to $\mathrm{PC}$ - and $\mathrm{H}_{2}$-treated mice. However, with $\mathrm{PC}$ and $\mathrm{H}_{2}$ treatment, the $\mathrm{Ca}^{2+}$ level was found to be decreased in both groups compared to the TMT-only group but without significant differences in both the serum and brain lysates. Furthermore, we evaluated the effects of $\mathrm{H}_{2}$ inhalation on the TMT-induced MDA level. As shown in Figure 5C, the MDA level in the TMT-only $(p<0.01)$, PC $(p<0.05)$, and $\mathrm{H}_{2}(p<0.01)$ groups was significantly increased in the serum of TMT-injected mice 
compared with those of the NC mice. In contrast, we found a significantly increased MDA level in the TMT-only group in brain lysates compared with those of the NC mice. However, with $\mathrm{PC}$ and $\mathrm{H}_{2}$ administration, the level of MDA was significantly decreased in the PC- $(p<0.01)$ and $\mathrm{H}_{2}$-treated $(p<0.001)$ groups compared with the TMT-only group (Figure 5D). These results demonstrated that TMT effectively induced damage in the brain by increasing intracellular $\mathrm{Ca}^{2+}$ and MDA levels, while $\mathrm{H}_{2}$ treatment effectively repaired the damage caused by TMT and might have therapeutic effects.

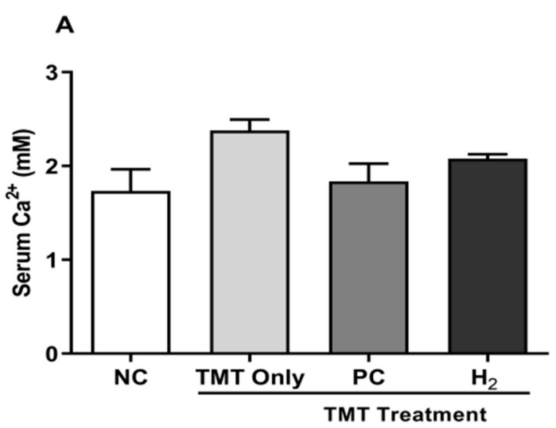

c

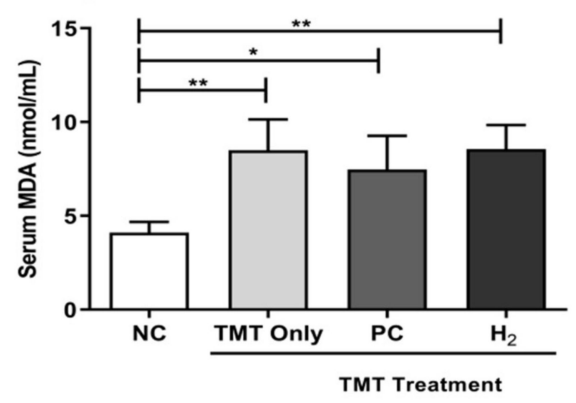

B

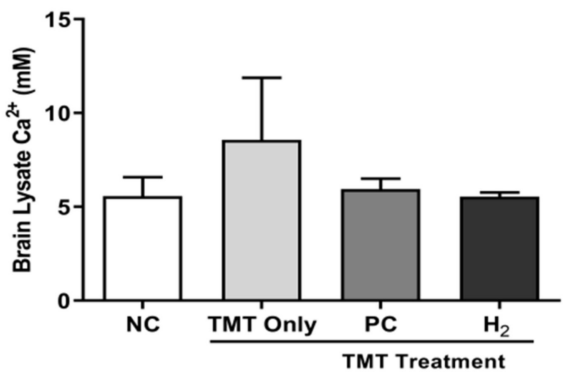

D

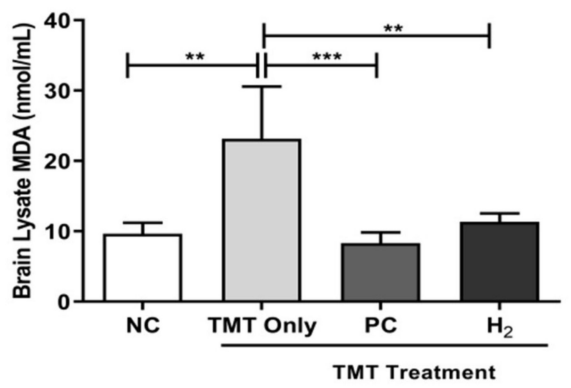

Figure 5. Effects of $\mathrm{H}_{2}$ gas inhalation treatment on $\mathrm{Ca}^{2+}$ and MDA levels in TMT-induced C57BL/6 mice after four weeks. (A) Serum $\mathrm{Ca}^{2+}$ level, (B) Brain lysate $\mathrm{Ca}^{2+}$ level, (C) Serum MDA level, (D) Brain lysate MDA level. Data are shown as the mean \pm SEM for $n=4$ mice. Significant differences were analyzed with ANOVA and Tukey's test. ${ }^{*} p<0.05,{ }^{* *} p<0.01,{ }^{* * *} p<0.001$.

\subsection{Effects of $\mathrm{H}_{2}$ Gas Inhalation on Antioxidative Enzyme Activities in Mice Serum and Brain under TMT-Induced Damage}

To investigate the effects of $\mathrm{H}_{2}$ gas inhalation on OS imbalance under TMT-induced damage, we measured the activities of antioxidative enzymes, such as catalase and glutathione peroxidase activity (GPx), in the serum and brain lysates. Our results showed that catalase activity in serum was significantly decreased in the NC- $(p<0.05)$ and $\mathrm{H}_{2}$-treated groups $(p<0.05)$ compared with those of the TMT-only group (Figure 6A). In addition, our brain lysate result showed a significantly decreased catalase level in $\mathrm{H}_{2}$-treated group $(p<0.01)$ compared with the TMT-only group (Figure 6B). Moreover, we investigated the GPx level in both the serum and brain lysates. Our results showed significantly decreased GPx activity in both the NC- $(p<0.01)$ and $\mathrm{H}_{2}$-treated $(p<0.05)$ groups in serum (Figure $\left.6 \mathrm{C}\right)$. Likewise, we found significantly decreased GPx activity in the brain lysates of the NC$(p<0.05)$, PC- $(p<0.05)$, and $\mathrm{H}_{2}$-treated $(p<0.05)$ groups compared with the TMT-only group (Figure 6D). These results demonstrated that elevated catalase and GPx levels in the serum and brain with TMT induction may reflect a compensatory rise in antioxidants in response to oxidative damage. 

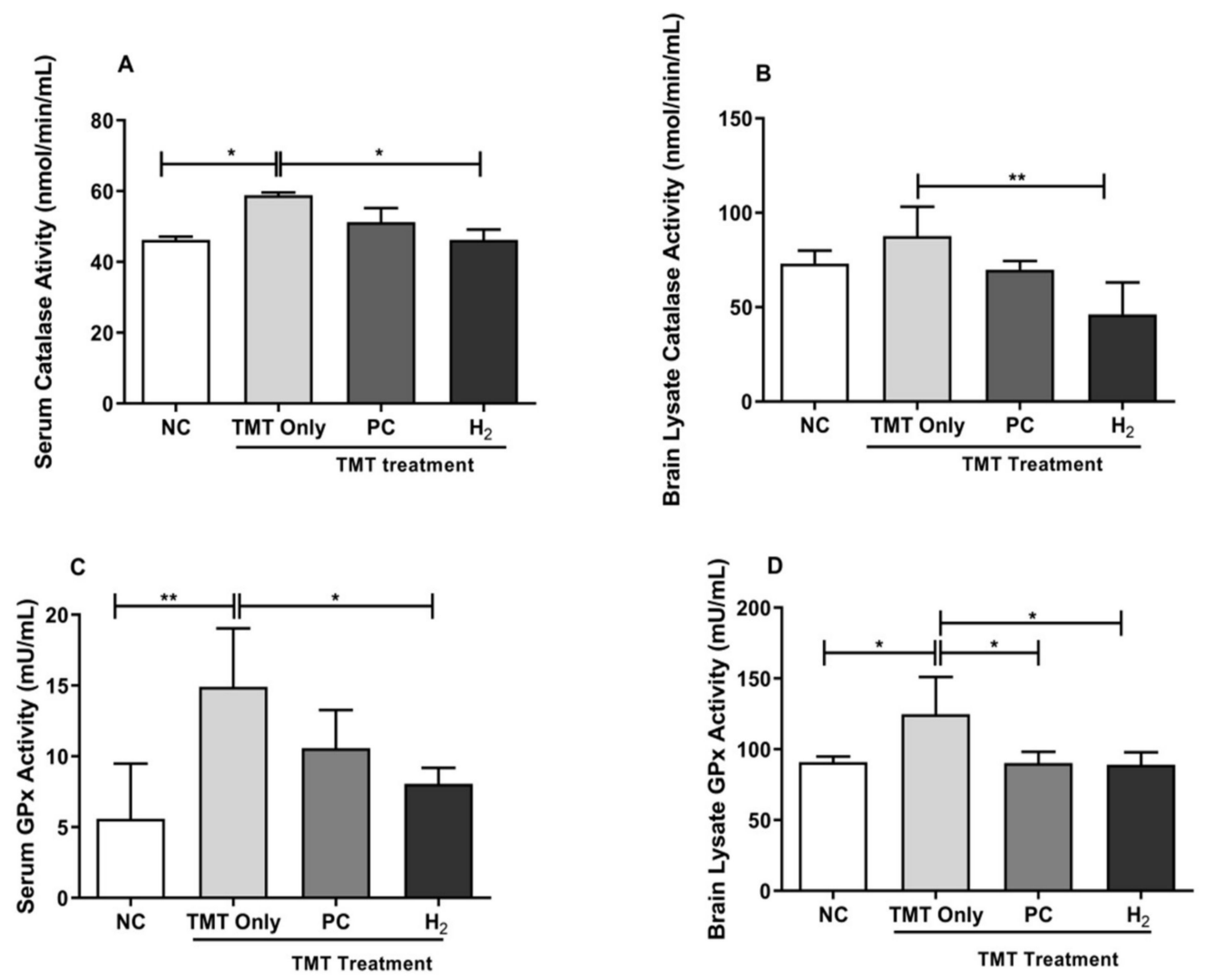

Figure 6. Effects of $\mathrm{H}_{2}$ gas inhalation treatment on total intracellular catalase and GPx levels in TMT-induced C57BL/ 6 mice after four weeks. (A) Serum catalase level, (B) Brain lysate catalase level, (C) Serum GPx level, (D) Brain lysate GPx level. Data are shown as the mean \pm SEM for $\mathrm{n}=4$ mice. Significant differences were analyzed with ANOVA and Tukey's test. ${ }^{*} p<0.05,{ }^{* *} p<0.01$.

\subsection{Effects of $\mathrm{H}_{2}$ Gas Inhalation on Inflammatory Cytokines and Vascular Endothelial Growth Factor in Mice Serum and Brain under TMT-Induced Damage}

It is well established that TMT-induction plays a role in neuroinflammation [13,23]. Therefore, we investigated the expression of inflammatory cytokines, such as granulocyte colony-stimulating factors (G-CSF) and TNF- $\alpha$, and vascular endothelial growth factor (VEGF) in the serum and brain lysates. Our results showed that the administration of TMT significantly decreased the G-CSF level in serum compared with the NC- $(p<0.01)$, PC- $(p<0.05)$, and $\mathrm{H}_{2}$-treated $(p<0.05)$ groups (Figure 7A). In addition, TNF- $\alpha$ level was significantly increased in the TMT-only group; however, with $\mathrm{PC}$ and $\mathrm{H}_{2}$ treatment, the level of TNF- $\alpha$ (inflammatory cytokines) in serum was significantly decreased in the PC$(p<0.01)$ and $\mathrm{H}_{2}$-treated $(p<0.01)$ groups (Figure 7B). Moreover, we measured the VEGF level in the serum of mice. Our results showed that the level of VEGF was significantly decreased in the TMT-only group $(p<0.01)$ and the PC- $(p<0.05)$ and $\mathrm{H}_{2}$-treated $(p<0.05)$ groups compared with the NC group (Figure 7C).

Furthermore, our brain lysates results showed a significant reduction in the G-CSF level in the PC-treated $(p<0.05)$ and $\mathrm{H}_{2}$ - treated $(p<0.05)$ groups compared with the TMTonly group (Figure $8 \mathrm{~A}$ ). In addition, the level of IL-1 $\beta$ cytokine was markedly increased in the TMT-only group but decreased in the NC, $\mathrm{PC}$, and $\mathrm{H}_{2}$-treated groups without a significant difference (Figure 8B). Moreover, the TNF- $\alpha$ level was significantly increased in the TMT-only group; however, with PC and $\mathrm{H}_{2}$ treatment, the level of TNF- $\alpha$ in the brain lysates was significantly decreased in the $\mathrm{H}_{2}$-treated group $(p<0.01)$ (Figure $8 \mathrm{C}$ ). Additionally, VEGF expression was significantly increased in the $\mathrm{H}_{2}$-treated group compared to the TMT-only group (Figure 8D). Collectively, these results indicate that $\mathrm{H}_{2}$ effectively 
attenuated TMT-induced neurotoxicity and cognitive damage by inhibiting inflammatory cytokines and upregulating VEGF.
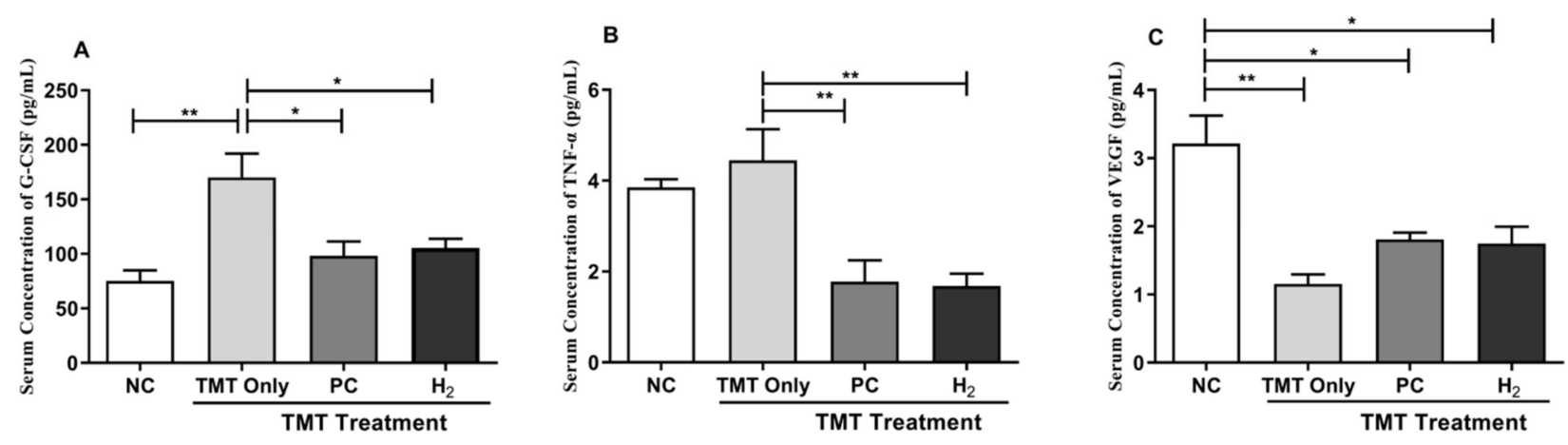

Figure 7. Effects of $\mathrm{H}_{2}$ gas inhalation treatment on inflammatory cytokines and VEGF in serum in TMT-induced C57BL/6 mice after four weeks. (A) G-CSF, (B) TNF- $\alpha,($ C) VEGF. Data are shown as the mean \pm SEM for $\mathrm{n}=4$ mice. Significant differences were analyzed with ANOVA and Tukey's test. ${ }^{*} p<0.05,{ }^{* *} p<0.01$.
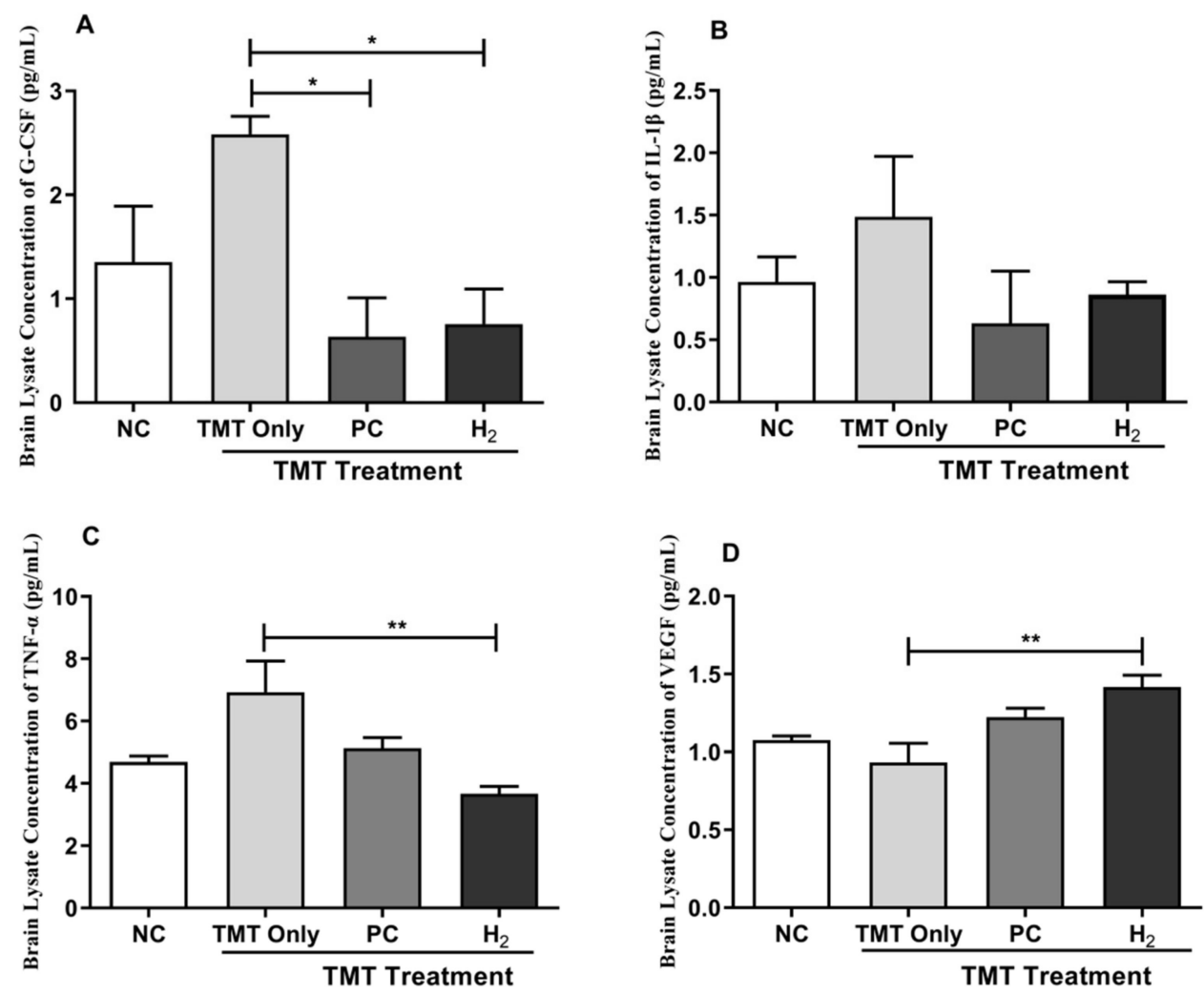

Figure 8. Effects of $\mathrm{H}_{2}$ gas inhalation treatment on inflammatory cytokines and VEGF level in brain lysates in TMT-induced C57BL/ 6 mice after four weeks. (A) G-CSF, (B) IL-1 $\beta$, (C) TNF- $\alpha$, (D) VEGF. Data are shown as the mean \pm SEM for $n=4$ mice. Significant differences were analyzed with ANOVA and Tukey's test. ${ }^{*} p<0.05,{ }^{* *} p<0.01$.

\subsection{Effects of $\mathrm{H}_{2}$ Gas Inhalation on Intracellular Apolipoprotein E Activities in Mice Serum and Brain under TMT-Induced Damage}

The apolipoprotein E (Apo-E) gene is strongly associated with the risk of AD [37]. To verify the role of TMT-induction in Apo-E activity, we further evaluated total Apo-E levels in blood and brain lysates using ELISA. We found that Apo-E levels in serum were significantly increased in the TMT-only group $(p<0.05)$ compared to the NC group, whereas 
in the brain lysate, Apo-E activity was significantly decreased in the PC- $(p<0.001)$ and $\mathrm{H}_{2}$ treated $(p<0.001$ ) groups compared with the TMT-only group (Figure 9A,B). Taken together, our results showed that TMT induction of Apo-E levels effectively induced brain damage and was associated with $\mathrm{AD}$ progression, whereas $\mathrm{H}_{2}$ treatment effectively improved brain damage associated with progression of TMT-induced AD.
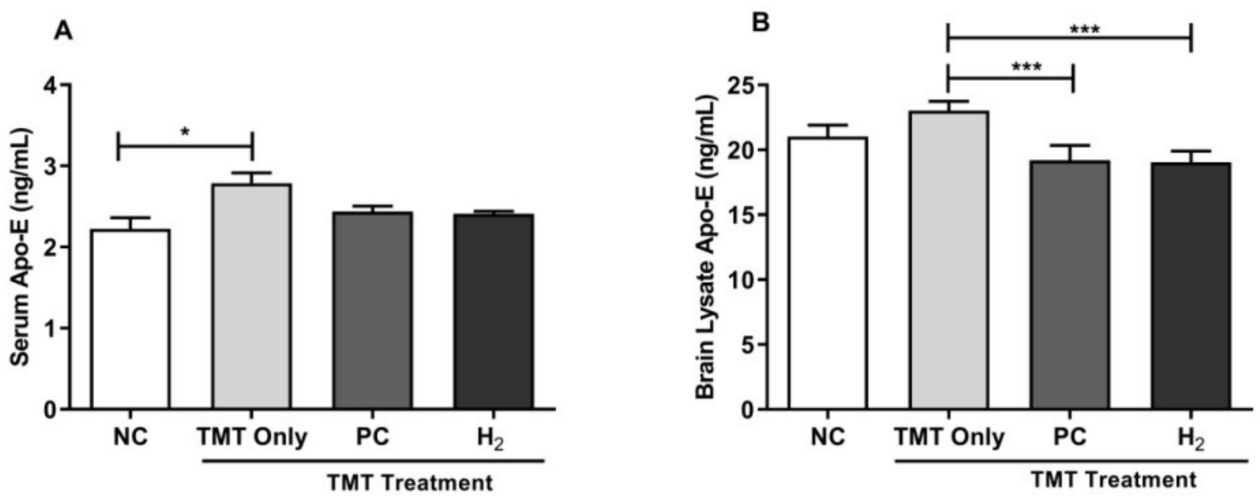

Figure 9. Effects of $\mathrm{H}_{2}$ gas inhalation treatment on intracellular Apo-E activities in TMT-induced C57BL/ 6 mice after four weeks. (A) Serum Apo-E level, (B) Brain lysate Apo-E level. Data are shown as the mean \pm SEM for $\mathrm{n}=4$ mice. Significant differences were analyzed with ANOVA and Tukey's test. ${ }^{*} p<0.05,{ }^{* * *} p<0.001$.

\subsection{Effects of $\mathrm{H}_{2}$ Gas Inhalation on AD-Related Biomarkers in Brain Tissue under TMT-Induced Damage}

We verified the underlying molecular mechanisms of $\mathrm{H}_{2}$ gas inhalation on TMTinduced neurotoxicity and cognitive impairment and evaluated the protein expression of AD-related biomarkers such as A $\beta-40$ and phospho-tau (p-tau)-(Ser404) by western blot analysis. In our results, we observed various sizes of bands of $A \beta$ oligomers/aggregates in mouse brain lysates. In addition, we observed that a wide range of $A \beta$ molecules such as oligomers and aggregates with increasing molecular size was intensified in the TMT-induced group compared to the NC group, indicating that AD was induced in the hippocampus following TMT induction. However, with PC and $\mathrm{H}_{2}$ treatment, the expressions of $A \beta-40$ oligomers/aggregates were found to be decreased compared to the TMT-only group (Figure 10A). Similarly, we found the expression levels of p-tau-(Ser404) were significantly increased in the TMT-only group $(p<0.001)$ compared with the NC group; however, with PC $(p<0.05)$ and $\mathrm{H}_{2}(p<0.001)$ treatment, the expression of $\mathrm{p}$-tau-(Ser404) was significantly decreased (Figure 10B).

\subsection{Effects of $\mathrm{H}_{2}$ Gas Inhalation on Bcl-2 and Bcl-Associated X Protein in Brain Tissue under TMT-Induced Damage}

We investigated the underlying molecular mechanisms of $\mathrm{H}_{2}$ gas inhalation against TMT-induced neurotoxicity and evaluated the protein expression of Bcl-2- and Bcl-2associated X (Bax) protein by western blot analysis. We found that the expression level of Bcl-2 was significantly decreased in the TMT-only group $(p<0.001)$ compared to the NC group. However, with PC $(p<0.01)$ and $\mathrm{H}_{2}(p<0.001)$ treatment, the expression of Bcl-2 was significantly increased (Figure 11A). In contrast, we found that the expression levels of Bax were significantly increased in the TMT-only group $(p<0.001)$ compared to the NC group; however, with PC $(p<0.01)$ and $\mathrm{H}_{2}(p<0.001)$ treatment, the expression of Bax was significantly decreased compared to the TMT-only group (Figure 11B), indicating that TMT-induced apoptosis was attenuated by $\mathrm{H}_{2}$ gas inhalation treatment in the brain. 


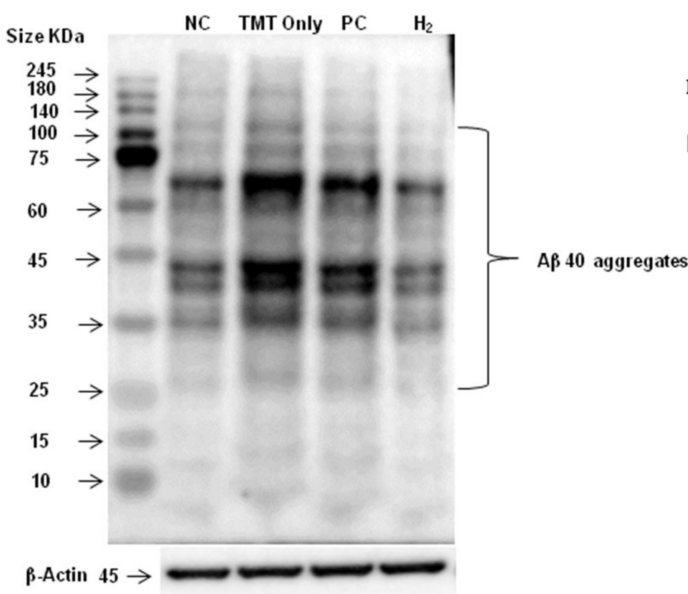

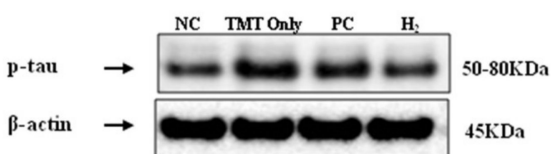

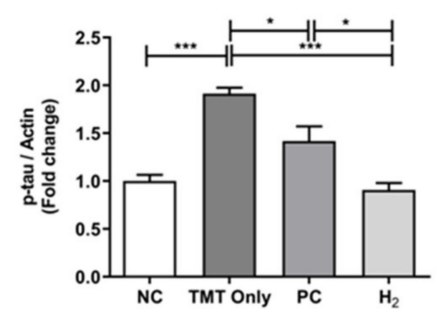

Figure 10. Effects of $\mathrm{H}_{2}$ gas inhalation treatment on the $\mathrm{A} \beta-40$ (mouse monoclonal- 32A1) and p-tau-(Ser404) protein levels in brain lysates in TMT-induced C57BL/6 mice after four weeks. (A) The antibody-reactive bands of mouse $A \beta-40$ in the brain lysates, (B) The antibody-reactive band of p-tau-(Ser404) protein levels in brain lysates. The bar graphs represent the band intensity of each protein marker normalized to the total. The data are presented as the mean $\pm \mathrm{SD}$ of $\mathrm{n}=3$ mice. Significant differences were analyzed with ANOVA and Tukey's test. ${ }^{*} p<0.05,{ }^{* * *} p<0.001$.
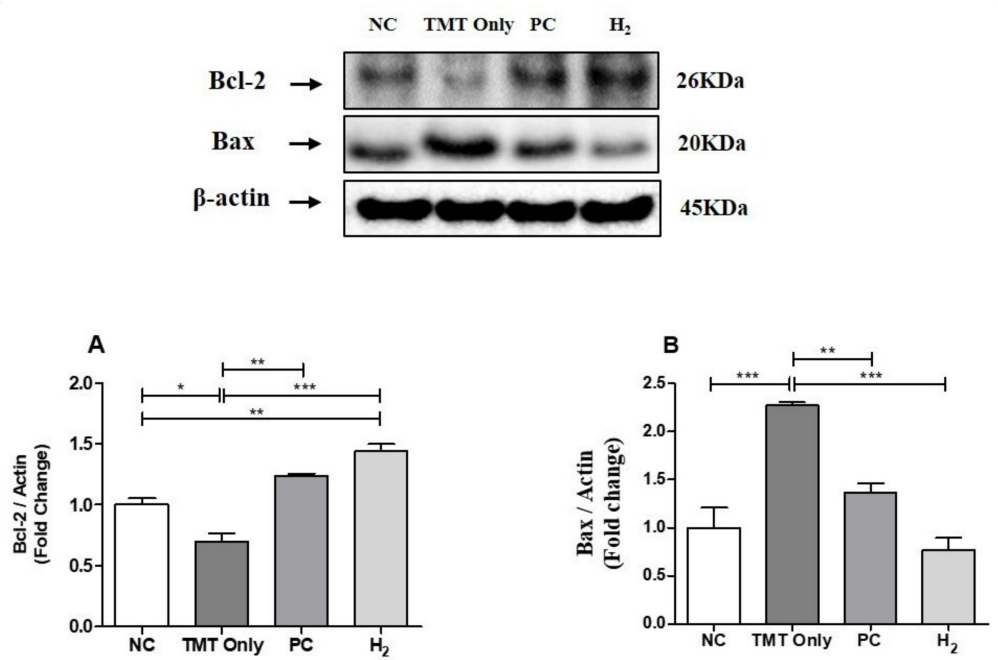

Figure 11. Effects of $\mathrm{H}_{2}$ gas inhalation treatment on the Bcl-2 and Bax protein levels in brain lysates of TMT-induced C57BL/6 mice after four weeks. (A) The antibody-reactive quantified band intensity of Bcl-2 in the brain lysates, (B) The antibody-reactive quantified band intensity of Bax protein in brain lysates. The bar graphs represent the band intensity of each protein marker normalized to the total. The data are presented as the mean \pm SD for $n=3$ mice. Significant differences were analyzed with ANOVA and Tukey's test. ${ }^{*} p<0.05,{ }^{* *} p<0.01,{ }^{* * *} p<0.001$.

\section{Discussion}

The present study investigated the therapeutic effects of $\mathrm{H}_{2}$ gas inhalation on TMTinduced neurotoxicity and cognitive impairment in mice. Our findings indicate that $\mathrm{H}_{2}$ gas treatment ameliorated TMT-induced OS and inflammatory and AD-related markers in C57BL/ 6 mice. Several studies have reported that neurodegenerative diseases are characterized by progressive neuronal death, resulting in the loss of neurons in specific areas, such as the hippocampal region of the brain, causing spatial cognitive impairment such as $\mathrm{AD}[2,3,38]$. Recently, research in the $\mathrm{H}_{2}$ field has been emerging due to its high biosafety and effectiveness as a medical gas $[39,40]$. Studies have shown that $\mathrm{H}_{2}$ is highly capable 
of penetrating the biological membranes including the BBB. Thus, this characteristic of $\mathrm{H}_{2}$ provides unrestricted access to the CNS, causing therapeutic effects on many CNS diseases, including ischemia stroke, intracranial hemorrhage, and neurodegenerative diseases [41-44]. Moreover, previous studies have shown that administration of $\mathrm{H}_{2}$ inhalation attenuated redox stress, inflammatory and OS mediators, and prevented BBB disruption by reducing the activation of mast cells and degranulation that result in amelioration of neurological conditions [24,39,41]. In addition, studies have shown that inhalation of $\mathrm{H}_{2}$ gas $(1-4 \%)$ was effective for the improvement of acute and chronic neurological conditions in different clinical and animal models [31,39]. Additionally, one of the recent studies has confirmed the safety and effectiveness of administration of $3 \% \mathrm{H}_{2}$ on acute cerebral infarction patients [31]. Moreover, administration of $2 \% \mathrm{H}_{2}$ gas inhalation alleviated BBB impairment and memory dysfunction in the brain through regulation of antioxidative pathways in mice [45]. Therefore, the attenuation of neuronal death through $\mathrm{H}_{2}$ treatment might be a novel strategy for the prevention and treatment of cognitive impairments such as $\mathrm{AD}$.

TMT is a commonly used neurotoxin for constructing in vivo models of neurodegenerative diseases such as AD since TMT injection can specifically alter conditions such as tremors, seizures, and spatial recognition memory, which are associated with hippocampal dysfunction in the brain. Animals exposed to TMT experience spontaneous seizures and elevated neuronal excitability $[13,15,16]$. Interestingly, studies have reported that $\mathrm{H}_{2}$ has potential to protect against many neurological diseases, including cerebral injury, neuropathic pain, cognitive impairment, and AD [32,46-48]. Our results showed that TMT induction induces aggressive behavior, seizures, whole body tremors, and memory deficits in mice. Moreover, reduction in seizure behavior and improved memory were observed following repeated $\mathrm{H}_{2}$ gas inhalation in mice. Therefore, these results suggest that repeated administration of $\mathrm{H}_{2}$ gas attenuates TMT-induced toxicity in the hippocampal region of the brain. However, detailed investigations are required to verify this claim.

Compelling evidences suggest that extracellular $A \beta$ plaques and hyperphosphorylated tau protein are the key pathological hallmarks in $\mathrm{AD}$ [4-6]. The deposition and aggregation of $\mathrm{A} \beta$ plaques and hyperphosphorylated tau proteins lead to excessive production of ROS and RNS that cause OS, chronic neuroinflammation, and dysfunction in mitochondrial function in the brain, causing neuronal loss and protein misfolding $[49,50]$. In TMT-induced neurotoxicity and damage, OS is considered one of the main mechanisms underlying neurodegeneration. Previous evidences have shown that TMT induces ROS, RNS, and MDA (lipid peroxidation marker) both in vivo and in vitro [51-53]. These oxidative conditions could affect behavioral abnormalities and imbalance of the antioxidant defense system and consequently cause neuronal cell death in TMT-induced animals [51,52]. In addition, endogenous compensatory antioxidative responses are activated simultaneously in the brain for the recovery of various neurological damage conditions, such as TMT induction. A previous study showed that $\mathrm{H}_{2}$ selectively reduced highly toxic $\mathrm{ROS}$ such as hydroxyl radical and peroxynitrite and protected the cells against OS [24]. In addition, another study showed that administration of $\mathrm{H}_{2}$ decreased OS-related markers such as hydroxyl-2-nonenal, NO, and MDA in patients and rodents [54]. In our study, we observed a significant increase in intracellular ROS, NO, and MDA levels in the TMT-induced mice, whereas $\mathrm{H}_{2}$ gas treatment significantly attenuated these oxidative markers in both the brain and blood. In contrast, our results showed that the activities of antioxidant enzymes such as catalase and GPx were increased in the TMT-induced group and decreased in the PC and $\mathrm{H}_{2}$ groups. This might be due to the compensatory mechanism of the antioxidant defense system against TMT-induced damage. Moreover, previous publications on hydrogen effects have reported that the administration of $\mathrm{H}_{2}$ alleviates neurotoxicity by decreasing levels of OS biomarkers $[3,25]$. Several studies have reported a connection between $\mathrm{Ca}^{2+}$ homeostasis disruption and the development of neuro-diseases such as AD [55,56]. Moreover, at the cellular level, it has been reported that abnormal amyloid accumulation induces an upregulation of neuronal $\mathrm{Ca}^{2+}$ signaling. Excessive $\mathrm{Ca}^{2+}$ release from the endoplasmic 
reticulum plays an important role in orchestrating the dynamics of the neuropathology of $\mathrm{AD}$ and associated memory loss and cognitive dysfunction [55,56]. Additionally, one study reported that TMT-intoxicated injection dysregulated intracellular $\mathrm{Ca}^{2+}$ in hippocampal neurons [15]. Toward this, a previous study conducted on hydrogen administration demonstrated that exposure of cultured cells to $\mathrm{H}_{2}$-dependently autoxidized phospholipid species reduced the $\mathrm{Ca}^{2+}$ signal and mediated the expression of different genes [35]. Our present results revealed that TMT-induction increased the values of intracellular $\mathrm{Ca}^{2+}$ activity in both the serum and brain tissue. In addition, our findings show that $\mathrm{H}_{2}$ gas administration reduced the values of the upregulated intercellular $\mathrm{Ca}^{2+}$ activity in the blood and brain. Taken together, these results indicate that administration of $\mathrm{H}_{2}$ could effectively attenuate the OS markers both systematically and induced by TMT intoxication in mice brain, as well as aid recovery from TMT-induced neuronal damage.

Increasing evidence shows that neuroinflammation plays a vital role in the progression of $\mathrm{AD}$ pathogenesis. Inflammation is not only known to be the key pathophysiological mechanism of $\mathrm{A} \beta$ plaques formation, but it is also a main cause of tau hyperphosphorylation, NFT formation, and neurodegeneration $[57,58]$. Chronically, neurotoxins such as A $\beta$ can activate microglia to release cytotoxic factors, such as superoxide $\left(\mathrm{O}_{2}{ }^{-}\right), \mathrm{NO}, \mathrm{TNF}-\alpha$, and IL- $1 \beta$ in the brain that reliably trigger neuronal death $[59,60]$. Another study reported that patients with AD had higher levels of pro-inflammatory cytokines, such as IL-4, IL-10, G-CSF, monocyte chemotactic protein 1, and TNF- $\alpha$ [61]. In contrast, VEGF signaling proteins have been reported to have protective effects against cognitive impairment [62]. Additionally, a study reported that TMT intoxication in mice induced neuronal death and the enhancement of inflammatory factors, including TNF- $\alpha$ and IL- $1 \beta$, in the hippocampus [60]. Studies on $\mathrm{H}_{2}$ have reported anti-inflammatory actions [32,54,63]. A recently published study on $\mathrm{H}_{2}$ also demonstrated anti-inflammatory action in $3 \times \mathrm{Tg}$-AD mice [64]. In the present study, we examined cytokines such as G-CSF, IL- $1 \beta$, TNF- $\alpha$, and VEGF in blood and brain tissues to investigate the effects of $\mathrm{H}_{2}$ administration on TMT-induced cognitive damage. Our findings indicate that TMT intoxication in mice significantly increased the levels of inflammatory cytokines such as G-CSF and TNF- $\alpha$ in the blood, which were attenuated following four weeks of $\mathrm{H}_{2}$ gas administration. Additionally, $\mathrm{H}_{2}$ treatment inhibited the expression of inflammatory cytokines, such as G-CSF, IL- $1 \beta$, and TNF- $\alpha$, in the brain tissue induced with TMT. Moreover, we found that $\mathrm{H}_{2}$ treatment increased the VEGF protein levels in both blood and brain tissues in mice under TMT-induction. Thus, we may conclude that $\mathrm{H}_{2}$ administration in TMT-induced mice exhibited repairing effects, which resulted in reduced TMT-induced neurotoxic damage by inhibiting inflammatory mediators, such as inflammatory cytokines, and improving cognitive function.

Furthermore, a previous study revealed that the Apo-E protein is associated with a greater memory decline rate and cognitive dysfunction in patients with mild cognitive impairment [65]. Apo-E plays an important role in tau pathology, in the presence of $A \beta$, in the progression of $\mathrm{AD}$, and in the decline of cognitive function [66]. Additionally, it is known that accumulation and fibrillary deposition of the $\mathrm{A} \beta$ peptide in senile plaques and tau phosphorylation in neurofibrillary tangles are the major causes of cognitive dysfunction. In addition, toxic oligomers are generated in brain by accumulation of $A \beta$, which triggered OS-induced damage, neuroinflammation, hyperphosphorylation of tau, and dysregulation of metabolic pathways [4]. A study conducted by Park et al., reported that TMT induction increased the p-tau expression in TMT-induced mice [67]. Accordingly, a previous conducted a study on $\mathrm{H}_{2}$ showed amelioration of TMT-induced spatial learning and memory impairment in mice by regulation of Siah-1 [36]. In the present study, we evaluated the cognitive improvement effects of $\mathrm{H}_{2}$ in TMT-induced mice by measuring the Apo-E levels in the blood and brain. Our results revealed a significant increase in Apo-E levels in both the blood and brain of TMT-induced mice. On the other hand, $\mathrm{H}_{2}$ administration in mice for four weeks after TMT-induction significantly decreased Apo-E levels in the brain. Additionally, we measured $A \beta-40$ and p-tau protein expressions using western blot in the TMT-induced hippocampal brain samples. Our results showed that 
$\mathrm{A} \beta-40$ and $\mathrm{p}$-tau protein expressions were significantly increased in the TMT-only group, whereas with $\mathrm{H}_{2}$ and PC treatment, expressions of $A \beta-40$ and p-tau were significantly attenuated in TMT-induced mice.

It is well known that apoptosis is an important mechanism for TMT-induced hippocampal neuronal toxicity and damage $[13,16,17]$. Bcl-2 and Bax play important roles in promoting apoptosis whereas their roles are functionally opposite. Bcl-2 is known as the key cell apoptosis protein marker, whereas Bax acts to promote apoptosis. In a previous study, administration of hydrogen-rich saline showed improved neurological function and decreased neuronal apoptosis in rabbits by upregulation of Bcl-2 and downregulation of the Bax protein in subarachnoid hemorrhage [68]. Therefore, investigation of the relationship between TMT-induction and $\mathrm{H}_{2}$ treatment and changes in Bcl-2 and Bax expression is intriguing $[53,69]$. Further, to explore the mechanism underlying the therapeutic effects of $\mathrm{H}_{2}$ inhalation in TMT-induced mice, we assessed the expression of Bcl-2 and the Bax protein. Our results showed that Bcl-2 expression was decreased in the TMT-only group, while Bax expression was increased in the TMT-only group. In contrast, $\mathrm{H}_{2}$ treatment reversed the alteration of Bcl-2 and Bax. Together, these data indicate that $\mathrm{H}_{2}$ inhalation ameliorated the TMT-induced toxicity and cognitive impairment in mice by inhibiting hippocampal apoptosis through Bcl-2 and Bax signaling pathways. Based on these overall findings, we can conclude that $\mathrm{H}_{2}$ administration in TMT-induced mice improved cognitive function and neurotoxic damage due to its antioxidative and anti-inflammatory effects.

\section{Materials and Methods}

\subsection{Animals}

Twenty-four male C57BL/ 6 mice (20-24 g, 8-9 weeks) were purchased from Orient Bio Inc. (Seongnam, Korea). The mice were kept in a pathogen-free environment $\left(22 \pm 2{ }^{\circ} \mathrm{C}\right.$ with $50 \pm 10 \%$ humidity) under a 12 -h light/dark cycle. The mice were given rodent chow and filtered water ad libitum until the end of the experiment. The mice were acclimatized for 10 days in plastic cages $(390 \times 275 \times 175 \mathrm{~mm})$ with wood shaving bedding and were randomly divided into four different groups ( $\mathrm{n}=6$ per group): non treated normal control group (NC), TMT-only injection group (TMT Only), TMT injection + lithium chloride (LC)-treated group as a positive control (PC), and TMT injection $+2 \% \mathrm{H}_{2}$ inhalation-treated group $\left(\mathrm{H}_{2}\right)$. All experimental procedures were performed in accordance with the protocol of the Institutional Animal Care and Use Committee, Yonsei University Wonju College of Medicine (Ethical approval no: YWC-191115-1).

\subsection{Experimental Design}

This experiment was designed as shown in Figure 1. TMT (Sigma-Aldrich, St. Louis, $\mathrm{MO}$, USA) was dissolved in sterilized $0.9 \%$ saline, and a single dose of $2.6 \mathrm{mg} / \mathrm{kg}$ was injected ip into the mice except the NC group. For the PC group, lithium chloride (SigmaAldrich, St. Louis, MO, USA) (50 mg/kg body weight) was administered twice by ip injection at 0 and $24 \mathrm{~h}$ after TMT injection. Previous conducted studies have shown LC as a potent neuroprotective agent, found to ameliorate neurodegeneration, neuroinflammation, neurotoxicity, and behavioral disability in a TMT-induced hippocampal neurodegeneration model $[70,71]$. For the treatment of the $\mathrm{H}_{2}$ group, $2 \% \mathrm{H}_{2}$ gas was produced from a $\mathrm{H}_{2}$-generating device designed and provided by the company (GOOTZ Co., Ltd., Suwon, Korea). The mice were administered $2 \% \mathrm{H}_{2}$ gas for 30 min once a day for four weeks. To investigate the effect of $\mathrm{H}_{2}$ inhalation, seizure behaviors were observed for four consecutive days after TMT treatment. Furthermore, to assess the TMT-induced memory deficits, hippocampus-dependent memory tests (Y-maze memory test) were performed on the 7th day of TMT induction, at which time the seizure behavior had disappeared. Body weight was measured once per week for four weeks. At the end of the experiment, the mice were sacrificed using isoflurane anesthetic (Hana Pharm. Co., Hwaseong, Korea). After mice were sacrificed, their blood samples were collected from retro-orbital veins in EDTA tubes, and serum was separated by centrifugation at $14,000 \mathrm{rpm}$ for $5 \mathrm{~min}$ at $4{ }^{\circ} \mathrm{C}$. To 
obtain brain lysate samples, the heads of the mice were decapitated, and the hippocampal region of the brain was separated and homogenized in ice-cold RIPA lysis buffer (Pierce Biotechnology Inc., Rockford, IL, USA) with a protease inhibitor cocktail (Sigma Chemical Co., St. Louis, MO, USA) using the bead milling method (QIAGEN Tissue Lyser II, manufactured by Retsch., Goleta, CA, USA) at 30 frequency/sec for $10 \mathrm{~min}$. Thereafter, the brain lysate homogenate was centrifuged at $14,000 \mathrm{rpm}$ for $10 \mathrm{~min}$ at $4{ }^{\circ} \mathrm{C}$, and the protein concentration of the obtained supernatant was checked using a bicinchoninic (BCA) protein assay kit (Takara Bio, Shiga, Japan) and normalized. Both collected serum and brain lysate samples were stored at $-80{ }^{\circ} \mathrm{C}$ until further use. Furthermore, ROS, NO, $\mathrm{Ca}^{2+}, \mathrm{MDA}, \mathrm{GPx}$, and catalase activities were measured as OS-related markers. G-CSF, IL-1 $\beta$, TNF- $\alpha$, and VEGF were measured as inflammation-related markers, and Bcl-2 and Bax as apoptotic markers. In addition, Apo-E, A $\beta-40$, and p-tau were measured as AD-related markers.

\subsection{Seizure Scoring and Body Weight Measurement}

Seizure and tremor behavior tests were performed in mice until four days after TMT induction. Scores were assigned for behavioral changes in mice, ranging from 1 (aggression), 2 (weak tremor), 3 (systemic tremor), 4 (tremor and spasmodic gait), to 5 (death) [31]. In addition, body weight measurements were conducted every week for four weeks to obtain the baseline data of all experimental mice.

\subsection{Y-Maze for Behavioral Test}

Seven days after TMT injection, a Y-maze behavioral test was performed in mice according to their grouping. The maze was made from black Y-shaped plastic, and the arms were at an angle of $120^{\circ}$ from each other. Each mouse was allowed to freely move in the maze for $8 \mathrm{~min}$, and the sequence of arm entries was recorded with a Smart 3.0 video tracking system (Panlab, Cambridge, MA, USA). The spatial cognition (\%) ability was calculated as follows: actual alternation / (total number of arm entries -2 ) $\times 100$. In addition, the total distance traveled in the zone was determined.

\subsection{Detection of the ROS Level}

ROS levels were measured using dichloro-dihydro-fluorescein diacetate (DCFH-DA) reagent (Sigma, St. Louis, MO, USA) following the manufacturer's instructions. Briefly, $10 \mu \mathrm{L}$ of serum and brain lysate samples and $100 \mu \mathrm{L}$ of $10 \mu \mathrm{M}$ DCFH-DA were mixed in a 96-well black plate and incubated for $30 \mathrm{~min}$ at $37^{\circ} \mathrm{C}$. The fluorescence was measured using a DTX multi-mode microplate reader (Beckman Coulter Inc., Brea, CA, USA) at $488 \mathrm{~nm}$ excitation $/ 525 \mathrm{~nm}$ emission.

\subsection{Detection of the NO Level}

NO levels were measured using Griess reagent (iNtRON Biotechnology, Sungnam, South Korea) following the manufacturer's instructions. Briefly, $50 \mu \mathrm{L}$ of serum and brain lysate samples were mixed with an equal volume of Griess reagent in a 96-well microplate and incubated at room temperature for $15 \mathrm{~min}$. The absorbance was measured at $540 \mathrm{~nm}$ using SpectraMax ${ }^{\circledR}$ ABS Plus (Molecular Devices, San Jose, CA, USA). The $\mathrm{NO}_{2}{ }^{-}$concentration was calculated by a standard curve graph that was generated by serial two-fold dilutions of sodium nitrate.

\subsection{Analysis of Antioxidant Enzyme Activities}

Intracellular levels of endogenous antioxidant enzymes (catalase and GPx) were measured using the BioVision kit (BioVision, Inc., Milpitas, CA, USA) following the manufacturer's instructions. Briefly, $78 \mu \mathrm{L}$ of samples $(10 \mu \mathrm{L}$ from stock and $68 \mu \mathrm{L}$ assay buffer $)$ for the catalase assay and $50 \mu \mathrm{L}$ of samples $(10 \mu \mathrm{L}$ from stock and $40 \mu \mathrm{L}$ assay buffer $)$ for the GPx assay were added to a 96-well microplate, and the plates were incubated for $30 \mathrm{~min}$. The optical densities of catalase $(570 \mathrm{~nm})$ and GPx $(340 \mathrm{~nm})$ were measured using 
SpectraMax ${ }^{\circledR}$ ABS Plus (Molecular Devices, San Jose, CA, USA). The results of the catalase and GPx activities were expressed in $\mathrm{nmol} / \mathrm{min} / \mathrm{mL}$ and $\mathrm{mU} / \mathrm{mL}$.

\subsection{Detection of $\mathrm{Ca}^{2+}$ Activity}

Intracellular $\mathrm{Ca}^{2+}$ activities were measured in serum and brain lysates using a $\mathrm{Ca}^{2+}$ colorimetric assay kit (BioVision, CA, USA) following the manufacturer's instructions. In brief, $50 \mu \mathrm{L}$ of each sample was added to a 96-well microplate, and the plate was incubated for $30 \mathrm{~min}$. The optical density was measured at $590 \mathrm{~nm}$ using SpectraMax ${ }^{\circledR}$ ABS Plus (Molecular Devices, San Jose, CA, USA). The results were expressed in mM.

\subsection{Detection of MDA Activity}

The level of MDA in serum and brain lysates was measured using a thiobarbituric acid reactive substances assay kit (BioVision, Milpitas, CA, USA). The assay was performed according to the manufacturer's instructions. The reaction product was measured colorimetrically at $532 \mathrm{~nm}$ using the SpectraMax ${ }^{\circledR}$ ABS Plus microplate reader (Molecular Devices, San Jose, CA, USA).

\subsection{Detection of Inflammatory Cytokines and Vascular Endothelial Growth Factor by Multiplex Assay}

Cytokine and chemokine profiling was performed using the Milliplex ${ }^{\circledR}$ MAP Mouse Cytokine/Chemokine Magnetic Bead Panel 96-well plate assay (Millipore Corporation, Billerica, MA, USA) as a luminex-based multiplex technology. G-CSF, IL-1 $\beta$, TNF- $\alpha$, and VEGF were measured by using a multiplex immunoassay following the manufacturer's protocol. In brief, each standard concentration was resuspended in standard diluents, and serial dilutions of the standard were prepared. The bead mixture was added to the standard and serum and brain lysates. The plate was incubated overnight $(18 \mathrm{~h})$ at $4{ }^{\circ} \mathrm{C}$ and was proceeded by a washing step. Detection antibody was added, and the plate was incubated at room temperature for $1 \mathrm{~h}$. A streptavidin-phycoerythrin mix was added, and the plate was incubated at room temperature for $30 \mathrm{~min}$. After the washing step, an assay buffer was added, and the plate was analyzed using the Luminex 200 Bio-Plex instrument.

\subsection{Detection of Total Apo-E by ELISA}

Apo-E levels in serum and brain lysates were detected using the Rat Apo-E ELISA kit (MyBioSource, Inc. San Diego, CA, USA), and analyses were performed according to the manufacturer's instructions. The concentration of Apo-E was visualized at $450 \mathrm{~nm}$ using a SpectraMax ${ }^{\circledR}$ ABS Plus spectrophotometer (Molecular Devices, San Jose, CA, USA), and the concentration of Apo-E was calculated using the standard curve.

\subsection{Western Blot Analysis}

The hippocampi of C57BL/ 6 mice were homogenized by using the bead milling method (QIAGEN Tissue Lyser II, manufactured by Retsch, Goleta, CA, USA) at 30 frequency/sec for $10 \mathrm{~min}$, incubated with $500 \mu \mathrm{L}$ lysis RIPA buffer at $4{ }^{\circ} \mathrm{C}$, and centrifuged at $14,000 \mathrm{rpm}$ for $10 \mathrm{~min}$. The liquid supernatant was collected, and the BCA protein assay kit (Takara, Shiga, Japan) was used to measure the total protein concentration. Equal amounts of protein samples $(20 \mu \mathrm{g})$ were separated on $12 \%$ polyacrylamide gels and transferred to a polyvinylidene difluoride membrane (Pall., Ann Arbor, MI, USA) at $300 \mathrm{~mA}$ for $2 \mathrm{~h}$. After transferal, the membranes were blocked with a blocking buffer (Takara, Shiga, Japan) for 1 $\mathrm{h}$ at room temperature. The membranes were further incubated with the primary antibodies Beta-actin (Cell Signaling Technology, Danvers, MA, USA), A $\beta-40$ (My Biosource, San Diego, CA, USA), phospho-tau-(Ser404) (Cell Signaling Technology, Danvers, MA, USA), Bcl-2 and Bax (Cell Signaling Technology, Danvers, MA, USA) in a 1:2000 dilution at $4{ }^{\circ} \mathrm{C}$ overnight. After washing three times with $1 \times$ Tris Buffered Saline and Tween $(1 \times$ TBST), the membranes were treated with horseradish peroxidase-(HRP) conjugated anti-rabbit secondary antibody (dilution 1:5000; Cell Signaling Technology) in $1 \times$ TBST for $2 \mathrm{~h}$ at 
room temperature. After washing three times, the bound antibodies were detected by an enhanced chemiluminescence kit (ECL Pierce Biotechnology, ThermoFisher Scientific, Waltham, MA, USA) using the UVP Bio Spectrum 600 Imaging System (UVP, LLC, Upland, CA, USA). Band intensity was analyzed using ImageJ software (Version 150-win Java, Bethesda, MD, USA).

\subsection{Data Management and Statistical Analysis}

Values are presented as the mean \pm standard error of the mean (SEM). All data were analyzed and compared by two-way analysis of variance (ANOVA), followed by a multiple comparison test using the Graph Pad Prism 8.0 software package (Graph Pad, La Jolla, CA, USA). Differences were considered to be statistically significant at $p<0.05$.

\section{Conclusions}

In summary, we evaluated the therapeutic effects of $\mathrm{H}_{2}$ gas inhalation on neurotoxicity and cognitive impairment in TMT-injected C57BL/6 mice. Our results showed that $\mathrm{H}_{2}$ gas inhalation effectively attenuated TMT-induced cognitive damage in mice. In addition, we found that $\mathrm{H}_{2}$ effectively decreased TMT-induced OS and inflammatory markers, such as ROS, NO, and MDA and inflammatory cytokines such as G-CSF, IL- $1 \beta$, and TNF- $\alpha$ in the blood and brain lysates of TMT-induced mice. In addition, $\mathrm{H}_{2}$ increased VEGF levels in both the serum and brain in TMT-induced mice. Furthermore, $\mathrm{H}_{2}$ inhalation decreased AD signaling protein markers such as Apo-E, A $\beta-40$, and p-tau in the brain of TMT-induced mice. In addition, $\mathrm{H}_{2}$ ameliorated the TMT-induced toxicity in mice by regulating hippocampal apoptosis through Bcl-2 and Bax signaling pathways. However, further molecular mechanistic studies on different signaling pathways are required to investigate the detailed therapeutic role of $\mathrm{H}_{2}$ inhalation in TMT-induced neurotoxicity and cognitive damage. Taken together, our results strongly suggest that $\mathrm{H}_{2}$ treatment might potentially be a future therapeutic candidate for neurodegenerative diseases by improving the cognitive abilities and controlling OS and inflammation-mediated neurodegeneration.

Author Contributions: Conceptualization, K.-J.L.; writing-original draft preparation, E.-S.J. and J.B. Formal analysis, J.B., C.-S.K. and E.-S.J.; writing-review and editing, C.-S.K., A.F. and J.B.; Experiment, J.B., E.-S.J., I.-S.Y., H.-U.K., S.S. and M.H.R.; preparation of figures, S.S. and M.H.R.; visualization, S.-Y.L. and C.-S.K.; supervision, K.-J.L. All authors have read and agreed to the published version of the manuscript.

Funding: This research was funded by GOOTZ Co., Ltd., Gyeonggi-do, Republic of Korea, grant number 2019-51-0299.

Institutional Review Board Statement: This study was performed in accordance with the protocol of the Institutional Animal Care and Use Committee, Yonsei University Wonju College of Medicine (Ethical approval no: YWC-191115-1).

Informed Consent Statement: Not applicable.

Data Availability Statement: All of the data are contained within the article.

Conflicts of Interest: The authors declare no conflict of interest.

\section{References}

1. Tarozzi, A. Oxidative stress in neurodegenerative diseases: From preclinical studies to clinical applications. J. Clin. Med. 2020, 9, 1223. [CrossRef]

2. Zhao, Y.; Zhao, B. Oxidative stress and the pathogenesis of Alzheimer's disease. Oxid. Med. Cell. Longev. 2013, $2013,316523$. [CrossRef]

3. Rahman, M.H.; Bajgai, J.; Fadriquela, A.; Sharma, S.; Thi, T.T.; Akter, R.; Goh, S.H.; Kim, C.S.; Lee, K.J. Redox effects of molecular hydrogen and its therapeutic efficacy in the treatment of neurodegenerative diseases. Processes 2021, 9, 308. [CrossRef]

4. Yu, H.; Wu, J. Amyloid- $\beta$ : A double agent in Alzheimer's disease? Biomed. Pharm. 2021, 139, 111575. [CrossRef] [PubMed]

5. Ji, C.; Sigurdsson, E.M. Current Status of Clinical Trials on Tau Immunotherapies. Drugs 2021, 8, 1135-1152. [CrossRef] [PubMed]

6. Xia, Y.; Prokop, S.; Giasson, B.I. “Don't Phos Over Tau”: Recent developments in clinical biomarkers and therapies targeting tau phosphorylation in Alzheimer's disease and other tauopathies. Mol. Neurodegener. 2021, 16, 37. [CrossRef] [PubMed] 
7. Cenini, G.; Lloret, A.; Cascella, R. Oxidative stress in neurodegenerative diseases: From a mitochondrial point of view. Oxid. Med. Cell. Longev. 2019, 2019, 2105607. [CrossRef] [PubMed]

8. Sbodio, J.I.; Snyder, S.H.; Paul, B.D. Redox mechanisms in neurodegeneration: From disease outcomes to therapeutic opportunities. Antioxid. Redox. Signal. 2019, 30, 1450-1499. [CrossRef]

9. Arimon, M.; Takeda, S.; Post, K.; Svirsky, S.; Hyman, B.T.; Berezovska, O. Oxidative stress and lipid peroxidation are upstream of amyloid pathology. Neurobiol. Dis. 2015, 84, 109-119. [CrossRef] [PubMed]

10. Park, J.C.; Han, S.H.; Mook-Jung, I. Peripheral inflammatory biomarkers in Alzheimer's disease: A brief review. BMB Rep. 2020, 53, 10-19. [CrossRef]

11. Yuliani, S.; Mustofa; Partadiredja, G. The neuroprotective effects of an ethanolic turmeric (Curcuma longa L.) extract against trimethyltin-induced oxidative stress in rats. Nutr. Neurosci. 2019, 22, 797-804. [CrossRef] [PubMed]

12. Kandlur, A.; Satyamoorthy, K.; Gangadharan, G. Oxidative stress in cognitive and epigenetic aging: A retrospective glance. Front. Mol. Neurosci. 2020, 13, 41. [CrossRef] [PubMed]

13. Geloso, M.C.; Corvino, V.; Michetti, F. Trimethyltin-induced hippocampal degeneration as a tool to investigate neurodegenerative processes. Neurochem. Int. 2011, 58, 729-738. [CrossRef] [PubMed]

14. Kreyberg, S.; Torvik, A.; Bjorneboe, A.; Wiik-Larsen, W.; Jacobsen, D. Trimethyltin poisoning: Report of a case with postmortem examination. Clin. Neuropathol. 1992, 11, 256-259.

15. Piacentini, R.; Gangitano, C.; Ceccariglia, S.; del Fa, A.; Azzena, G.B.; Michetti, F.; Grassi, C. Dysregulation of intracellular calcium homeostasis is responsible for neuronal death in an experimental model of selective hippocampal degeneration induced by trimethyltin. J. Neurochem. 2008, 105, 2109-2121. [CrossRef]

16. Lattanzi, W.; Corvino, V.; di Maria, V.; Michetti, F.; Geloso, M.C. Gene expression profiling as a tool to investigate the molecular machinery activated during hippocampal neurodegeneration induced by trimethyltin (TMT) administration. Int. J. Mol. Sci. 2013, 14, 16817-16835. [CrossRef] [PubMed]

17. Kim, Y.S. Magnolol protects against trimethyltin-induced neuronal damage and glial activation in vitro and in vivo. Neurotoxicology 2016, 53, 173-185. [CrossRef] [PubMed]

18. Kaur, S.; Nehru, B. Alteration in glutathione homeostasis and oxidative stress during the sequelae of trimethyltin syndrome in rat brain. Biol. Trace Elem. Res. 2013, 153, 299-308. [CrossRef] [PubMed]

19. Nilsberth, C.; Kostyszyn, B.; Luthman, J. Changes in app, ps1 and other factors related to Alzheimer's disease pathophysiology after trimethyltin-induced brain lesion in the rat. Neurotox. Res. 2002, 4, 625-636. [CrossRef] [PubMed]

20. Onaka, Y.; Wada, S.; Yamaguchi, T.; Yoneyama, M.; Ogita, K. Preventive effect of olanzapine on trimethyltin neurotoxicity in mice: Evaluation of hippocampal neuronal loss, microglial activation, and cognitive dysfunction. Glob. Drugs Ther. 2018, 3, 1-5. [CrossRef]

21. Ogita, K.; Nitta, Y.; Watanabe, M.; Nakatani, Y.; Nishiyama, N.; Sugiyama, C.; Yoneda, Y. In vivo activation of c-jun n-terminal kinase signaling cascade prior to granule cell death induced by trimethyltin in the dentate gyrus of mice. Neuropharmacology 2004, 47, 619-630. [CrossRef]

22. Harry, G.J.; Tyler, K.; d'Hellencourt, C.L.; Tilson, H.A.; Maier, W.E. Morphological alterations and elevations in tumor necrosis factor-alpha, interleukin (il)-1alpha, and il-6 in mixed glia cultures following exposure to trimethyltin: Modulation by proinflammatory cytokine recombinant proteins and neutralizing antibodies. Toxicol. Appl. Pharmacol. 2002, 180, 205-218. [CrossRef]

23. Kwon, O.Y.; Lee, S.H. Ishige okamurae suppresses trimethyltin-induced neurodegeneration and glutamate-mediated excitotoxicity by regulating mapks/nrf2/ho-1 antioxidant pathways. Antioxidants 2021, 10, 440. [CrossRef] [PubMed]

24. Ohsawa, I.; Ishikawa, M.; Takahashi, K.; Watanabe, M.; Nishimaki, K.; Yamagata, K.; Katsura, K.I.; Katayama, Y.; Asoh, S.; Ohta, S.; et al. Hydrogen acts as a therapeutic antioxidant by selectively reducing cytotoxic oxygen radicals. Nat. Med. 2007, 13, 688-694. [CrossRef]

25. Ichihara, M.; Sobue, S.; Ito, M.; Ito, M.; Hirayama, M.; Ohno, K. Beneficial biological effects and the underlying mechanisms of molecular hydrogen-Comprehensive review of 321 original articles. Med. Gas Res. 2015, 5, 12. [CrossRef] [PubMed]

26. Iketani, M.; Ohsawa, I. Molecular hydrogen as a neuroprotective agent. Curr. Neuropharmacol. 2017, 15, 324-331. [CrossRef]

27. Huang, L. Molecular hydrogen: A therapeutic antioxidant and beyond. Med. Gas Res. 2016, 6, 219-222. [CrossRef]

28. Guo, Q.; Yin, X.; Qiao, M.; Jia, Y.; Chen, D.; Shao, J.; Lebaron, T.W.; Gao, Y.; Shi, H.; Jia, B. Hydrogen-rich water ameliorates autistic-like behavioral abnormalities in valproic acid-treated adolescent mice offspring. Front. Behav. Neurosci. 2018, 12, 170. [CrossRef] [PubMed]

29. Bajgai, J.; Lee, K.J.; Rahman, M.H.; Fadriquela, A.; Kim, C.S. Role of molecular hydrogen in skin diseases and its impact in beauty. Curr. Pharm. Des. 2021, 27, 737-746. [CrossRef] [PubMed]

30. Imai, K.; Kotani, T.; Tsuda, H.; Mano, Y.; Nakano, T.; Ushida, T.; Li, H.; Miki, R.; Sumigama, S.; Iwase, A. Neuroprotective potential of molecular hydrogen against perinatal brain injury via suppression of activated microglia. Free Radic. Biol. Med. 2016, 91, 154-163. [CrossRef]

31. Ono, H.; Nishijima, Y.; Ohta, S.; Sakamoto, M.; Kinone, K.; Horikosi, T.; Takanami, H. Hydrogen gas inhalation treatment in acute cerebral infarction: A randomized controlled clinical study on safety and neuroprotection. J. Stroke Cerebrovasc. Dis. 2017, 26, 2587-2594. [CrossRef] 
32. Wang, C.; Li, J.; Liu, Q.; Yang, R.; Zhang, J.H.; Cao, Y.P.; Sun, X.J. Hydrogen-rich saline reduces oxidative stress and inflammation by inhibit of jnk and nf-kappab activation in a rat model of amyloid-beta-induced Alzheimer's disease. Neurosci. Lett. 2011, 491, 127-132. [CrossRef] [PubMed]

33. Gu, Y.; Huang, C.S.; Inoue, T.; Yamashita, T.; Ishida, T.; Kang, K.M.; Nakao, A. Drinking hydrogen water ameliorated cognitive impairment in senescence-accelerated mice. J. Clin. Biochem. Nutr. 2010, 46, 269-276. [CrossRef]

34. Yoritaka, A.; Takanashi, M.; Hirayama, M.; Nakahara, T.; Ohta, S.; Hattori, N. Pilot study of h2 therapy in Parkinson's disease: A randomized double-blind placebo-controlled trial. Mov. Disord. 2013, 28, 836-839. [CrossRef] [PubMed]

35. Iuchi, K.; Imoto, A.; Kamimura, N.; Nishimaki, K.; Ichimiya, H.; Yokota, T.; Ohta, S. Molecular hydrogen regulates gene expression by modifying the free radical chain reaction-dependent generation of oxidized phospholipid mediators. Sci. Rep. 2016, 6, 18971. [CrossRef] [PubMed]

36. Zhou, T.; Zhang, M.; Du, H.; Ablimit, A.; Ye, R.; Lü, M.; Chang, X.; Zhao, Q.; Wang, Y.; Qin, Q. Hydrogen rich water ameliorate Trimethyltin induced spatial learning and memory impairment by regulation of Siah-1. Res. Square. 2020, 1-8. [CrossRef]

37. Husain, M.A.; Laurent, B.; Plourde, M. Apoe and Alzheimer's disease: From lipid transport to physiopathology and therapeutics. Front. Neurosci. 2021, 15, 630502. [CrossRef] [PubMed]

38. Barnham, K.J.; Masters, C.L.; Bush, A.I. Neurodegenerative diseases and oxidative stress. Nat. Rev. Drug Discov. 2004, 3, 205-214. [CrossRef]

39. Dohi, K.; Satoh, K.; Miyamoto, K.; Momma, S.; Fukuda, K.; Higuchi, R.; Banks, W.A. Molecular hydrogen in the treatment of acute and chronic neurological conditions: Mechanisms of protection and routes of administration. J. Clin. Biochem. Nutr. 2017, 61, 1-5. [CrossRef] [PubMed]

40. Liu, B.; Xie, Y.; Chen, J.; Xue, J.; Zhang, X.; Zhao, M.; Qin, S. Protective effect of molecular hydrogen following different routes of administration on D-Galactose-induced aging mice. J. Inflamm. Res. 2021, 14, 5541. [CrossRef]

41. Manaenko, A.; Lekic, T.; Ma, Q.; Zhang, J.H.; Tang, J. Hydrogen inhalation ameliorated mast cell mediated brain injury after ICH in mice. Crit. Care. Med. 2013, 41, 1266-1275. [CrossRef] [PubMed]

42. Jiang, B.; Li, Y.; Dai, W.; Wu, A.; Wu, H.; Mao, D. Hydrogen-rich saline alleviates early brain injury through regulating of ER stress and autophagy after experimental subarachnoid hemorrhage. Acta Cir. Bras. 2021, 36, e360804. [CrossRef]

43. Ning, K.; Liu, W.W.; Huang, J.L.; Lu, H.T.; Sun, X.J. Effects of hydrogen on polarization of macrophages and microglia in a stroke model. Med. Gas. Res. 2018, 8, 154-159.

44. Kumagai, K.; Toyooka, T.; Takeuchi, S.; Otani, N.; Wada, K.; Tomiyama, A.; Mori, K. Hydrogen gas inhalation improves delayed brain injury by alleviating early brain injury after experimental subarachnoid hemorrhage. Sci Rep. 2020, 10, 12319. [CrossRef] [PubMed]

45. Yu, Y.; Feng, J.; Lian, N.; Yang, M.; Xie, K.; Wang, G.; Yu, Y. Hydrogen gas alleviates blood-brain barrier impairment and cognitive dysfunction of septic mice in an Nrf2-dependent pathway. Int. Immunopharmacol. 2020, 85, 106585. [CrossRef]

46. Nagata, K.; Nakashima-Kamimura, N.; Mikami, T.; Ohsawa, I.; Ohta, S. Consumption of molecular hydrogen prevents the stressinduced impairments in hippocampus-dependent learning tasks during chronic physical restraint in mice. Neuropsychopharmacology 2009, 34, 501-508. [CrossRef]

47. Shao, A.; Wu, H.; Hong, Y.; Tu, S.; Sun, X.; Wu, Q.; Sheng, J. Hydrogen-rich saline attenuated subarachnoid hemorrhageinduced early brain injury in rats by suppressing inflammatory response: Possible involvement of NF- $\mathrm{B}$ pathway and NLRP3 inflammasome. Mol. Neurobiol. 2016, 53, 3462-3476. [CrossRef] [PubMed]

48. Chen, Q.; Chen, P.; Zhou, S.; Yan, X.; Zhang, J.; Sun, X.; Yu, W. Hydrogen-rich saline attenuated neuropathic pain by reducing oxidative stress. Can. J. Neurol. Sci. 2013, 40, 857-863. [CrossRef] [PubMed]

49. Sharma, C.; Kim, S.R. Linking oxidative stress and proteinopathy in Alzheimer's disease. Antioxidants 2021, 10, 1231. [CrossRef] [PubMed]

50. Kent, S.A.; Spires-Jones, T.L.; Durrant, C.S. The physiological roles of tau and A $\beta$ : Implications for Alzheimer's disease pathology and therapeutics. Acta Neuropathol. 2020, 140, 1-31. [CrossRef] [PubMed]

51. Shin, E.J.; Suh, S.K.; Lim, Y.K.; Jhoo, W.K.; Hjelle, O.P.; Ottersen, O.P.; Shin, C.Y.; Ko, K.H.; Kim, W.K.; Kim, D.S.; et al. Ascorbate attenuates trimethyltin-induced oxidative burden and neuronal degeneration in the rat hippocampus by maintaining glutathione homeostasis. Neuroscience 2005, 133, 715-727. [CrossRef] [PubMed]

52. Huong, N.Q.; Nakamura, Y.; Kuramoto, N.; Yoneyama, M.; Nagashima, R.; Shiba, T.; Yamaguchi, T.; Hasebe, S.; Ogita, K. Indomethacin ameliorates trimethyltin-induced neuronal damage in vivo by attenuating oxidative stress in the dentate gyrus of mice. Biol. Pharm. Bull. 2011, 34, 1856-1863. [CrossRef] [PubMed]

53. Qu, M.; Zhou, Z.; Chen, C.; Li, M.; Pei, L.; Chu, F.; Yang, J.; Wang, Y.; Li, L.; Liu, C.; et al. Lycopene protects against trimethyltin-induced neurotoxicity in primary cultured rat hippocampal neurons by inhibiting the mitochondrial apoptotic pathway. Neurochem. Int. 2011, 59, 1095-1103. [CrossRef]

54. Ohno, K.; Ito, M.; Ichihara, M.; Ito, M. Molecular hydrogen as an emerging therapeutic medical gas for neurodegenerative and other diseases. Oxid. Med. Cell. Longev. 2012, 2012, 353152. [CrossRef] [PubMed]

55. Magi, S.; Castaldo, P.; Macri, M.L.; Maiolino, M.; Matteucci, A.; Bastioli, G.; Gratteri, S.; Amoroso, S.; Lariccia, V. Intracellular calcium dysregulation: Implications for Alzheimer's disease. Biomed. Res. Int. 2016, 2016, 6701324. [CrossRef]

56. Berridge, M.J. Dysregulation of neural calcium signaling in Alzheimer disease, bipolar disorder and schizophrenia. Prion 2013, 7 , 2-13. [CrossRef] 
57. Yang, Y.; Zhu, Y.; Xi, X. Anti-inflammatory and antitumor action of hydrogen via reactive oxygen species. Oncol. Lett. 2018, 16, 2771-2776. [CrossRef] [PubMed]

58. Du Yihong, S.Y.; Yang, R.; Wang, L.; Cai, M. Mechanisms of neuroinflammation in mild cognitive impairment. Chin. J. Tissue Eng. Res. 2021, 25, 4743.

59. Kinney, J.W.; Bemiller, S.M.; Murtishaw, A.S.; Leisgang, A.M.; Salazar, A.M.; Lamb, B.T. Inflammation as a central mechanism in Alzheimer's disease. Alzheimer's Dement. Transl. Res. Clin. Interv. 2018, 4, 575-590. [CrossRef] [PubMed]

60. Kim, D.J.; Kim, Y.S. Trimethyltin-induced microglial activation via nadph oxidase and mapks pathway in bv-2 microglial cells. Mediat. Inflamm. 2015, 2015, 729509. [CrossRef]

61. Taipa, R.; das Neves, S.P.; Sousa, A.L.; Fernandes, J.; Pinto, C.; Correia, A.P.; Santos, E.; Pinto, P.S.; Carneiro, P.; Costa, P.; et al. Proinflammatory and anti-inflammatory cytokines in the csf of patients with Alzheimer's disease and their correlation with cognitive decline. Neurobiol. Aging 2019, 76, 125-132. [CrossRef] [PubMed]

62. Garcia, K.O.; Ornellas, F.L.; Martin, P.K.; Patti, C.L.; Mello, L.E.; Frussa-Filho, R.; Han, S.W.; Longo, B.M. Therapeutic effects of the transplantation of vegf overexpressing bone marrow mesenchymal stem cells in the hippocampus of murine model of Alzheimer's disease. Front. Aging Neurosci. 2014, 6, 30. [CrossRef]

63. Kura, B.; Bagchi, A.K.; Singal, P.K.; Barancik, M.; LeBaron, T.W.; Valachova, K.; Slezák, J. Molecular hydrogen: Potential in mitigating oxidative-stress-induced radiation injury. Can. J. Physiol. Pharmacol. 2019, 97, 287-292. [CrossRef] [PubMed]

64. Lin, Y.T.; Shi, Q.Q.; Zhang, L.; Yue, C.P.; He, Z.J.; Li, X.X.; He, Q.J.; Liu, Q.; Du, X.B. Hydrogen-rich water ameliorates neuropathological impairments in a mouse model of Alzheimer's disease through reducing neuroinflammation and modulating intestinal microbiota. Neural Regen. Res. 2021, 17, 409-417.

65. Smith, G.E.; Bohac, D.L.; Waring, S.C.; Kokmen, E.; Tangalos, E.G.; Ivnik, R.J.; Petersen, R.C. Apolipoprotein e genotype influences cognitive 'phenotype' in patients with Alzheimer's disease but not in healthy control subjects. Neurology 1998, 50, 355-362. [CrossRef] [PubMed]

66. Shi, Y.; Yamada, K.; Liddelow, S.A.; Smith, S.T.; Zhao, L.; Luo, W.; Tsai, R.M.; Spina, S.; Grinberg, L.T.; Rojas, J.C.; et al. Apoe4 markedly exacerbates tau-mediated neurodegeneration in a mouse model of tauopathy. Nature 2017, 549, 523-527. [CrossRef]

67. Park, S.K.; Kang, J.Y.; Kim, J.M.; Yoo, S.K.; Han, H.J.; Chung, D.H.; Kim, D.O.; Kim, G.H.; Heo, H.J. Fucoidan-rich substances from ecklonia cava improve trimethyltin-induced cognitive dysfunction via down-regulation of amyloid beta production/tau hyperphosphorylation. Mar. Drugs 2019, 17, 591. [CrossRef]

68. Zhuang, Z.; Zhou, M.L.; You, W.C.; Zhu, L.; Ma, C.Y.; Sun, X.J.; Shi, J.X. Hydrogen-rich saline alleviates early brain injury via reducing oxidative stress and brain edema following experimental subarachnoid hemorrhage in rabbits. BMC Neurosci. 2012, 13, 1-10. [CrossRef] [PubMed]

69. Wen, D.; Hui, R.; Wang, J.; Shen, X.; Xie, B.; Gong, M.; Ma, C. Effects of molecular hydrogen on methamphetamine-induced neurotoxicity and spatial memory impairment. Front. Pharmacol. 2019, 10, 823. [CrossRef] [PubMed]

70. Kim, J.; Yang, M.; Kim, S.H.; Kim, J.C.; Wang, H.; Shin, T.; Moon, C. Possible role of the glycogen synthase kinase-3 signaling pathway in trimethyltin-induced hippocampal neurodegeneration in mice. PLoS ONE 2013, 8, e70356. [CrossRef] [PubMed]

71. Fabrizi, C.; Pompili, E.; Somma, F.; de Vito, S.; Ciraci, V.; Artico, M.; Fumagalli, L. Lithium limits trimethyltin-induced cytotoxicity and proinflammatory response in microglia without affecting the concurrent autophagy impairment. J. Appl. Toxicol. 2017, 37, 207-213. [CrossRef] [PubMed] 